A geochemical and micro-textural comparison of basalt-hosted chalcedony from the Jurassic Drakensberg and Neoarchean Ventersdorp Supergroup (Vaal River alluvial gravels), South Africa Elisabetta Gliozzo, Bruce Cairncross \& Torsten Vennemann

International Journal of Earth Sciences

GR Geologische Rundschau

ISSN 1437-3254

Int J Earth Sci (Geol Rundsch)

DOI 10.1007/s00531-019-01737-3
ONLINE FIRST

International Journal of Earth Sciences

GP CoologischeRundschau 
Your article is protected by copyright and all rights are held exclusively by Geologische Vereinigung e.V. (GV). This e-offprint is for personal use only and shall not be selfarchived in electronic repositories. If you wish to self-archive your article, please use the accepted manuscript version for posting on your own website. You may further deposit the accepted manuscript version in any repository, provided it is only made publicly available $\mathbf{1 2}$ months after official publication or later and provided acknowledgement is given to the original source of publication and a link is inserted to the published article on Springer's website. The link must be accompanied by the following text: "The final publication is available at link.springer.com". 


\title{
A geochemical and micro-textural comparison of basalt-hosted chalcedony from the Jurassic Drakensberg and Neoarchean Ventersdorp Supergroup (Vaal River alluvial gravels), South Africa
}

\author{
Elisabetta Gliozzo $^{1}$ (D) $\cdot$ Bruce Cairncross $^{2}$ (D) $\cdot$ Torsten Vennemann $^{3}$
}

Received: 28 February 2019 / Accepted: 16 May 2019

(c) Geologische Vereinigung e.V. (GV) 2019

\begin{abstract}
South African basalt-hosted chalcedonies provided an ideal case study, to (a) achieve information about the origin of mineralforming fluids, the process of chalcedony formation and weathering alteration and (b) to verify if the geochemical and microtextural characterization of chalcedony allowed multiple provenances to be distinguished. For the first time, Drakensberg chalcedonies from the Karoo Jurassic basalts and Windsorton chalcedonies from the alluvial environment of the Vaal River (traversing the Allanridge basaltic-andesitic lavas) were investigated by optical microscopy, laser ablation inductively coupled plasma mass spectroscopy and isotope ratio mass spectrometry $\left({ }^{16} \mathrm{O},{ }^{18} \mathrm{O}\right)$. The results showed that the compositional differences observed in Drakensberg and Windsorton chalcedonies could not be explained by changes in host rocks composition. The tholeiitic basaltic-andesitic lavas of the Allanridge Formation (Pniel Group, comparison term for Windsorton samples) and the tholeiitic basaltic-andesitic lavas of the Golden Gate Unit (Drakensberg Group, comparison term for Drakensberg specimens) proved to be very similar, also in terms of alteration degree. Conversely, both geochemical and oxygen isotope compositions clearly supported a relatively low temperature, hydrothermal origin for all the investigated chalcedonies, further indicating that differences mostly occurred during their formation (fluid circulation). Moreover, several characteristics suggested deposition in non-equilibrium conditions, although oxidizing conditions were most likely. Weathering processes were effective in the alluvial environment only, leading to a wider compositional heterogeneity of Windsorton chalcedonies with respect to Drakensberg samples. Lastly, a correlation between color and chromophores (Fe and Mn) amounts was lacking while a correlation between the geochemical composition and the texture was clearly observed in several specimens.
\end{abstract}

Keywords Chalcedony and agate $\cdot$ Volcanic host $\cdot$ Alluvial weathering $\cdot$ Hydrothermal fluids $\cdot$ LA-ICP-MS $\cdot$ Oxygen isotopes

Electronic supplementary material The online version of this article (https://doi.org/10.1007/s00531-019-01737-3) contains supplementary material, which is available to authorized users.

Elisabetta Gliozzo

gliozzo@unisi.it

Bruce Cairncross

brucec@uj.ac.za

1 Department of Earth, Environment and Physical Sciences, University of Siena, Siena, Italy

2 Department of Geology, University of Johannesburg, Auckland Park, PO Box 524, Johannesburg 2006, South Africa

3 Institut des Dynamiques de la Surface Terrestre, Université de Lausanne, 1015 Lausanne, Switzerland

\section{Introduction}

Given the complex and often debatable formation history and their worldwide occurrence, agates have received increasing attention in recent years. The seminal studies performed by Frondel (1962) provided the foundation for early research focusing on agate formation (e.g., Frondel 1978; Wang and Merino 1990; Heaney 1993; Heaney and Davis 1995; Landmesser 1995; Merino et al. 1995; Wang and Merino 1995; Landmesser 1998; Moxon et al. 2013; Götze et al. 2016). In addition, their banding phenomenon (e.g., Heaney and Davis 1995; Wang and Merino 1990, 1995; Götze et al. 1998; Moxon and Reed 2006; Götze et al. 2009), the formation temperature in volcanic environments (Fallick et al. 1985; Saunders 1990; Heaney 1993; Moxon 1996), their age of formation (e.g., Moxon 2017) as well as 


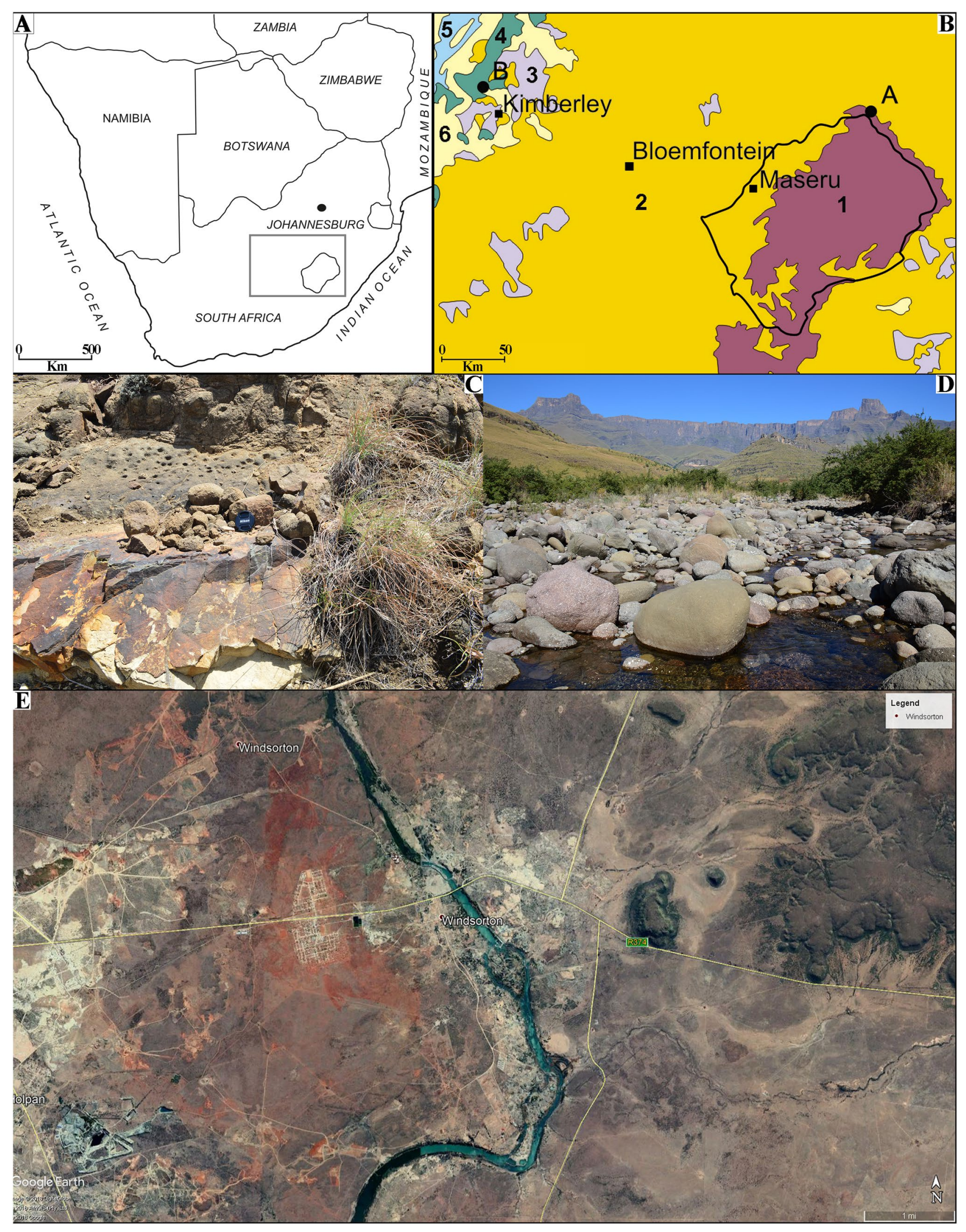


4Fig. 1 Agate sample sites in South Africa. a The rectangle in demarcated area in (a) is enlarged in (b) showing the sample sites in relation to the regional geology. $a$ agate sample site in Drakensberg Formation $28^{\circ} 32^{\prime} 4.37^{\prime \prime}$ South, $28^{\circ} 39^{\prime} 17.73^{\prime \prime}$ East. $b$ agate sample site from alluvial gravels $28^{\circ} 19^{\prime} 47.68^{\prime \prime}$ South, $24^{\circ} 43^{\prime} 36.63^{\prime \prime}$ East. Simplified geology: $1=$ Drakensberg Formation basalt; $2=$ Karoo Supergroup sedimentary strata (undifferentiated); $3=$ Karoo-age Jurassic dolerite; 4 =Ventersdorp Supergroup; $5=$ Transvaal Supergroup dolomite; $6=$ Quaternary sediment. c Sample site A. Camera lens cap $(6 \mathrm{~cm})$ is on the contact between underlying yellow Clarens Formation sandstone and overlying, weathered Drakensberg Formation basalt. The pitted hollows in the basalt are amygdales that have weathered and released agates (and other minerals). d Panoramic view of the Drakensberg Mountains at the Amphitheatre, South Africa. The flattopped skyline consists of Drakensberg Formation basalts (see Fig. 1) from which sample set A was obtained. The grassy slopes in the midrange are sandstones and siltstones of the upper Karoo Supergroup formations. The boulders in the foreground are alluvial fragments of basalt and are filled with white amygdales, the source of the agates. e Google Earth image of the Vaal River at Windsorton, Northern Cape Province, South Africa. The scarred landscape to the east of the town along the banks of the river are alluvial diamond mine diggings and dumps, where the agates (site B) were collected

other specific peculiarities (e.g., Götze et al. 2012, 2015) that may occur in some unique environments (e.g., Clark 2002; Moxon and Reed 2006; Moxon et al. 2006, 2007; Götze et al. 2009) or specific discovery contexts such as the archaeological excavations (e.g. Gliozzo et al. 2011, 2014), have received attention.

Compared to the worldwide occurrence of agates and to the range of topics that have been addressed for their study, the number of publications that have dealt with their geochemical composition are rather few (see Gliozzo 2019 for a comprehensive list of references). In particular, South African agate has rarely been investigated (Mountain 1953) although some work has been undertaken on Namibian agates (Harris 1988, 1989). Moreover, the fact that the oldest evidence of agate's heat treatment comes from the Middle
Stone Age in South Africa (Brown et al. 2009; Mourre et al. 2010; Porraz et al. 2013) has strongly focused this field of study towards the investigation of its behavior upon heating (Brown et al. 2009; Mourre et al. 2010; Wadley et al. 2017; Prinsloo et al. 2018).

In this manuscript, a collection of 36 South African chalcedonies and agates has been sampled from two geological environments-volcanic and alluvial — to provide their full geochemical characterization, as well as to compare and contrast the main distinguishing features between the two types of occurrences.

\section{Geological setting}

In South Africa, agates are well known from two different geological settings: the Drakensberg Group Jurassic basalts (Site A), that form most of the Kingdom of Lesotho, and the alluvial gravels deposited by the Vaal River (Site B), that drains part of central South Africa (Fig. 1a, b).

\section{Site A: Drakensberg Group}

The first set of chalcedonies was collected southeast of the town of Clarens (close to the northeastern border with Lesotho), from the basal lava flow of the Drakensberg Group, close to the contact with the underlying Clarens Formation sandstone (Fig. 1c).

The Drakensberg Group is the uppermost lithostratigraphical unit of the Carboniferous-Jurassic Karoo Supergroup (Duncan and Marsh 2006). ${ }^{40} \mathrm{Ar} /{ }^{39} \mathrm{Ar}$ ages of plagioclase from five lava flows covering the entire sequence in neighboring Lesotho have given a precise Lower Jurassic age of $182.3 \pm 1.6$ to $181.0 \pm 2.0 \mathrm{Ma}$ (Jourdan et al. 2007). The strata are composed of low $\mathrm{Ti}-\mathrm{Zr}$ tholeiitic basalt that can
Fig. 2 The 21 samples from the Drakensberg. Banding is clearly observable in samples nos. D4, 17 and 19 (agates), barely visible in samples nos. $3,6,8$ and 12 (chalcedonies/agates), absent in all the other chalcedonies. The red full circles indicate where the LA-ICP-MS measurements were performed. As for samples D4, 17 and 19, the numbers correspond to the analysis ID as provided in Supplementary Table 1

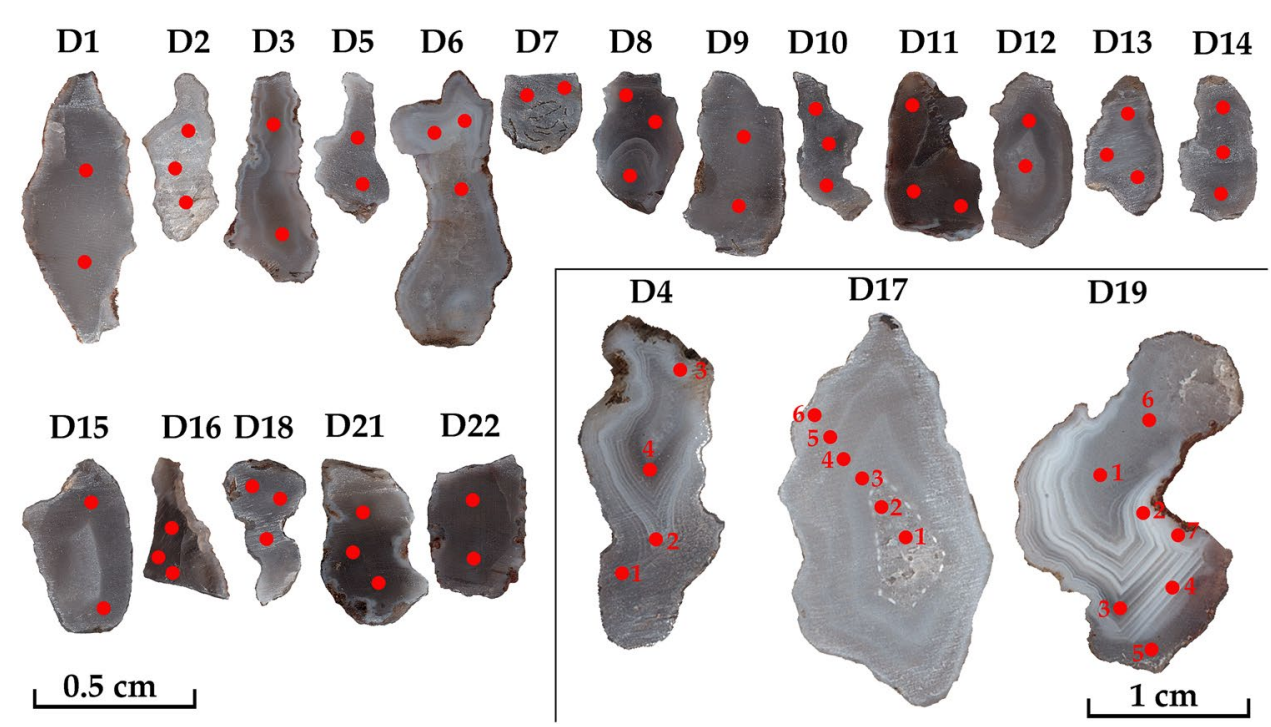


DRAKENSBERG
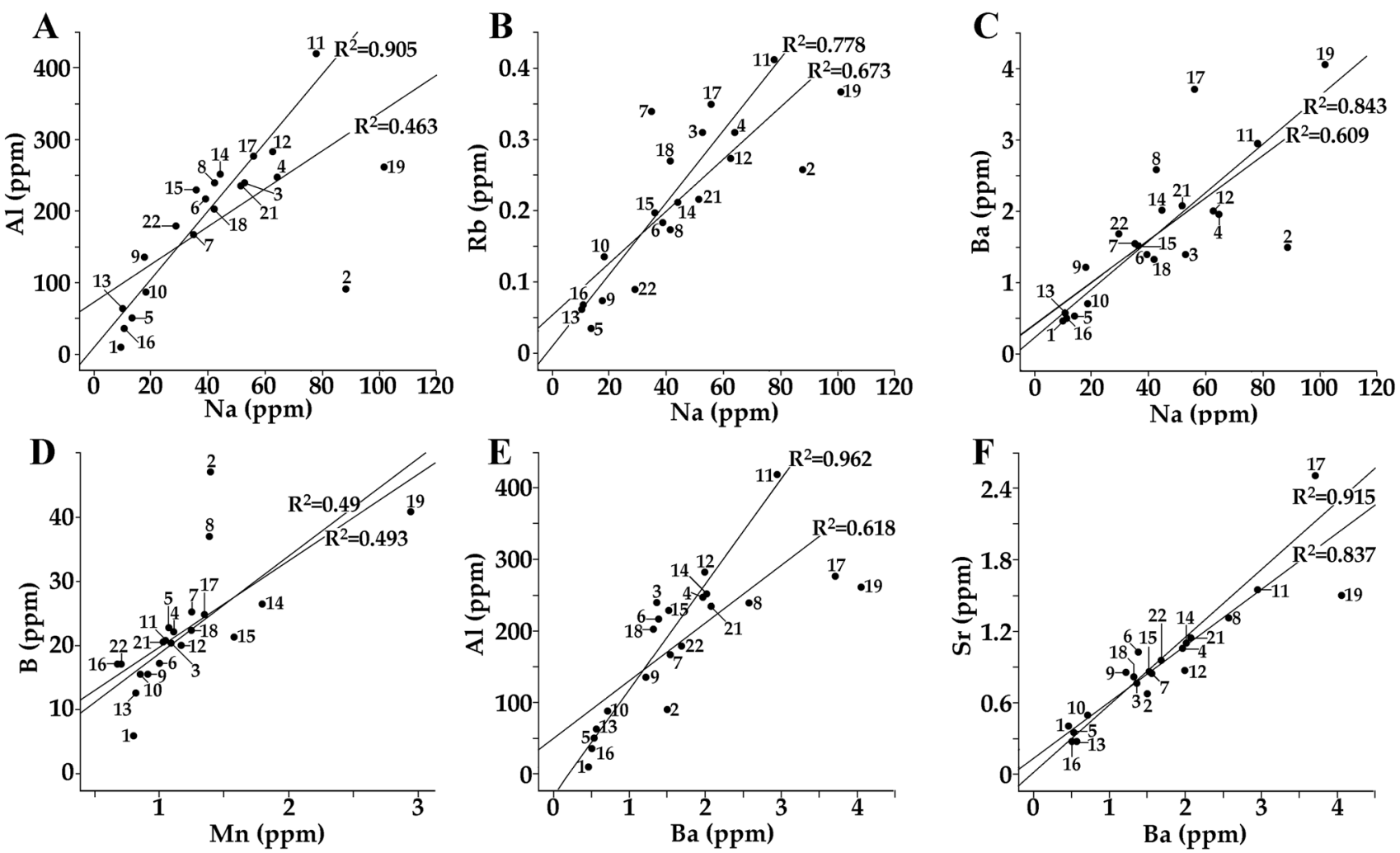

\section{WINDSORTON}
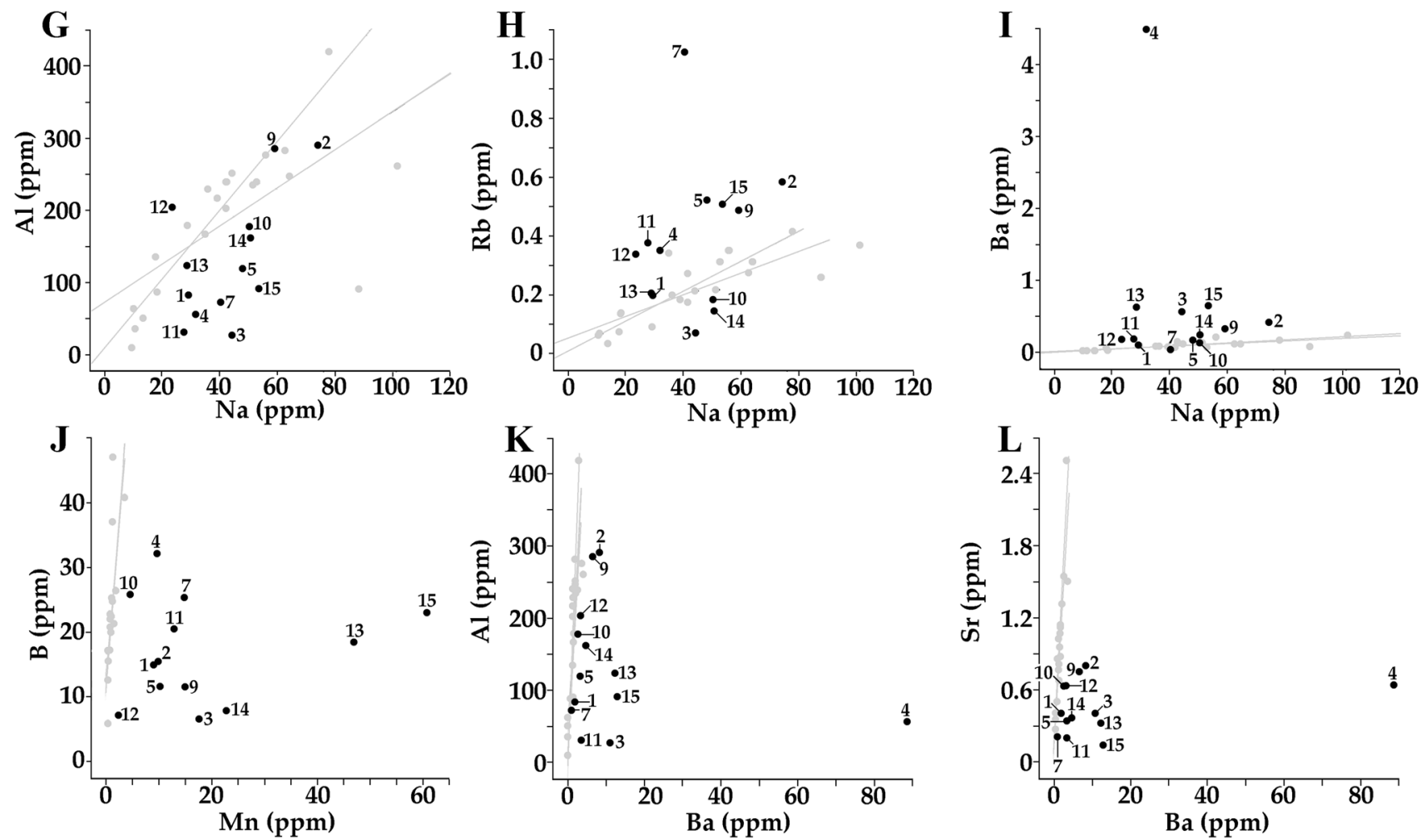
4 Fig. 3 Binary plots showing the geochemical variation of Drakensberg (a-f) and Windsorton (g-l) samples. In Drakensberg binary diagrams $(\mathbf{a}-\mathbf{f})$, the following samples were excluded from $R^{2}$ calculations: a-f D7; c D2 and D17; d D2 and D19; e D2, 17 and D19; f D17 and D19. In Windsorton binary diagrams (g-1), black full circles indicate Windsorton samples while grey full circles in the background represent the Drakensberg Group samples. The outlier sample Win6 has been omitted

be geochemically subdivided into recognizable units (Rhodes and Krohn 1972; Duncan et al. 1984; Marsh and Eales 1984; Marsh et al. 1997) with the entire volcanic sequence (in Lesotho) reaching a maximum thickness of $1650 \mathrm{~m}$. However, this is a remnant of the original thickness of the volcanic pile as it has been estimated that $600-700 \mathrm{~m}$ have been denuded from the land surface during the past $100 \mathrm{Ma}$ (Brown et al. 2002; Sumner et al. 2009). The lithostratigraphy is, therefore, relatively well constrained not only in Lesotho but also in South Africa (Lock et al. 1974; Pemberton 1978; Ramluckan 1992; Mitchell et al. 1996).

The Clarens Formation-informally termed the Golden Gate unit (Duncan and Marsh 2006) - is the lowermost basaltic unit. These basalts are highly amygdaloidal (Fig. 1d) and contain abundant vesicles filled with secondary minerals such as chalcedony (agate), natrolite and other secondary minerals such as calcite, epistilbite, heulandite, stellerite, laumontite, mesolite, mordenite and quartz (Dunlevey et al. 1993; Cairncross and Dixon 1995; Cairncross 2004), apophyllite and pyrite (Cairncross and du Plessis 2018). Furthermore, epigenetic deposits of laumontite are known to occur within the basalts and the Clarens Formation sandstone (Potgieter et al. 1982).

\section{Site B: Vaal River alluvial gravels at Windsorton}

The second set of agate samples was collected from the alluvial diamond workings on the Vaal River at Windsorton in the Northern Cape Province (Fig. 1e). Alluvial diamond mining has been taking place in South Africa since 1866 when the first alluvial diamond was found (e.g., Wilson et al. 2007). Since then, the gravels of the Vaal River and the Orange River, which drain diamond-bearing kimberlite terrains, have been worked for alluvial diamonds. One of the offshoots of this mining are the resultant gravel dumps that are ubiquitous surrounding the diggings. Included in the water-worn, rounded alluvial cobbles, pebbles and boulders are agates that originate from the areas drained by the rivers. The likely source of Windsorton gravels is the Ventersdorp Supergroup lavas (van der Westhuizen et al. 2006) based on three considerations. Firstly, the agate-bearing lithologies have to be sourced in the stretch of the Vaal River which connects Windsorton to the upstream Bloemhof Dam (approximately $130 \mathrm{~km}$ upstream), in view of the fact that this dam acts as a sink for all sediment and any alluvium carried downstream. Secondly, the agates were sampled from uppermost, younger alluvial gravel dumps at Windsorton, therefore, they do not correlate with older alluvium, deposited by palaeodrainage systems (Partridge and Brink 1967; McCarthy 1983). Thirdly, the Vaal River traverses the Allanridge Formation (van der Westhuizen et al. 2006) which is the most likely source of the agates. This is supported by Keyser (1998) description of this Formation, north of Windsorton: "Amygdales occur in both types of lavas (dark-green amygdaloidal lava and light-green-grey porphyritic lava) but are more common in the dark-green variety. It consists of quartz, chalcedony, calcite, chlorite or epidote or any combinations of these minerals". Within the uppermost volcanic Ventersdorp Supergroup formations (Makwassie, Rietgat and Allanridge Formations), the Allanridge lavas are basaltic-andesitic in composition. As for chronology, quartz porphyry rhyolites of the Makwassie Formation-that underlies the Allanridge F-have been dated at $2720 \pm 2 \mathrm{Ma}$ (Cornell et al. 2017).

\section{Materials and methods}

The collection from Site A (Drakensberg) includes 21 samples, rarely exceeding $3 \mathrm{~cm}$ in size. The predominant color is grey, but brown (samples D8, 11, 16, 21 and 22) and very light blue (sample D4) specimens have been found as well. The specimens D4, 17 and 19 have clear banding (henceforth called agates) while in samples 2, 3, 6, 8 and 12 banding is barely visible (henceforth called chalcedonies/ agates). All the other samples were rather homogeneous, with limited changes in the shade of grey color (henceforth called chalcedonies).

The collection from Site B (Windsorton) consists of 14 agates, ranging in size from 1.8 to $6.3 \mathrm{~cm}$. The samples show both wall lining (e.g., sample no. 2) and horizontal banding (e.g., sample no. 8) and a preferential brown to dark brown color. Orange colors were found in samples nos. 1 and 11 only, while samples nos. 5, 9 and 12 were nearly black.

To achieve a complete geochemical characterization of the chalcedonies and agates, all 35 were analyzed by laser ablation inductively coupled plasma mass spectroscopy (LA-ICP-MS) at IGG-CNR in Pavia, Italy. The instrument combined an ablation microbeam, based on a Nd:YAG laser source (Brilliant, Quantel) operating at $266 \mathrm{~nm}$ (for details see Tiepolo et al. 2003), and a quadrupole ICP-MS (Drc-e, Perkin Elmer). Forty masses were acquired; the laser was operated at $10 \mathrm{~Hz}$ of repetition rate, the power on the sample was $1.5 \mathrm{~mW}$ and spot size was set at $40 \mu \mathrm{m}$. Accuracy was assessed on the USGS BCR-2 reference glass (analysed as an unknown in each analytical run) and was better than $20 \%$ at the sub ppm level. Data reduction was carried out with the 
Fig. 4 a The agates (D4, 17 and 19) from the Drakensberg: the geochemical composition of the bands. In the $\mathrm{Fe}$ and $\mathrm{Mn}$ patterns, D and L stands for dark and light colour of the agates bands. This information has not been given for sample D17 which is homogeneously light in colour. b-c Binary plots showing the geochemical variation with respect to samples colours in the Drakensberg (b) and Windsorton (c) samples. Legend: very light grey (empty circles); light blue (empty square); dark grey (full grey circles); dark brownish (black cross); blackish (full black circles)
A $\quad$\begin{tabular}{|l|ll} 
& 1 & 2
\end{tabular}
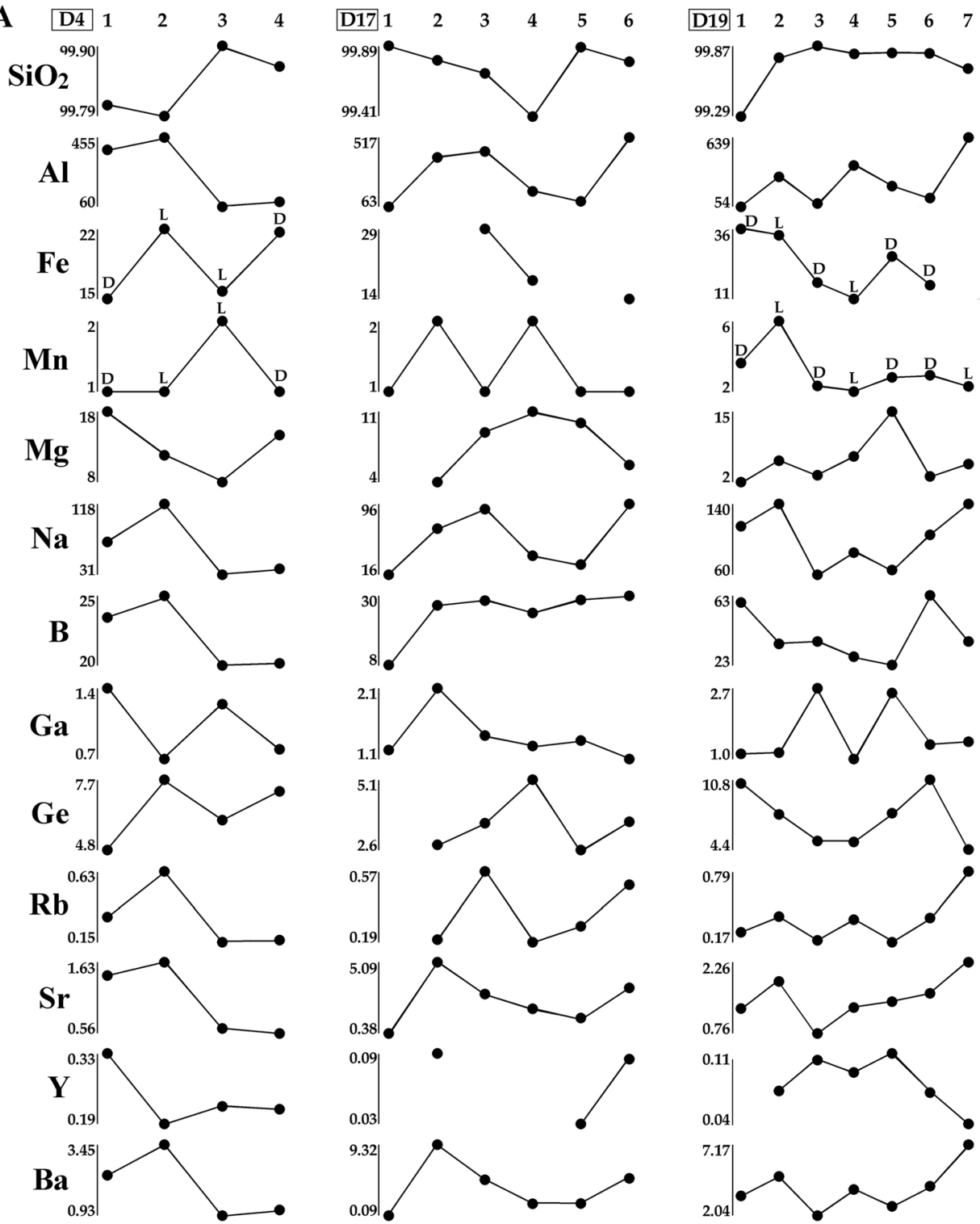

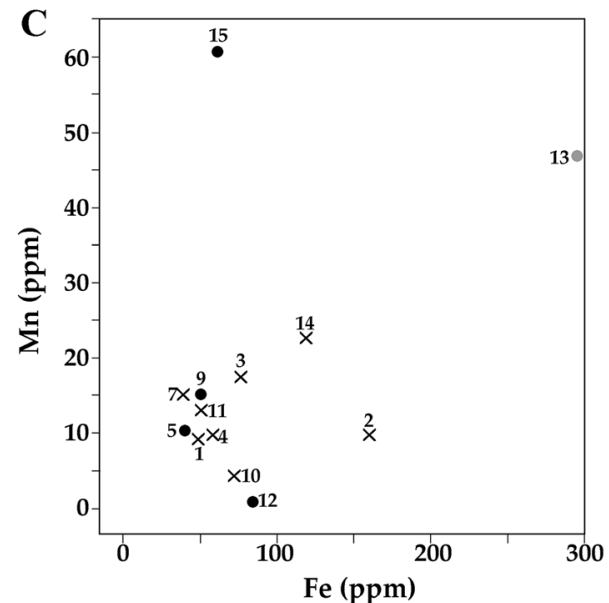



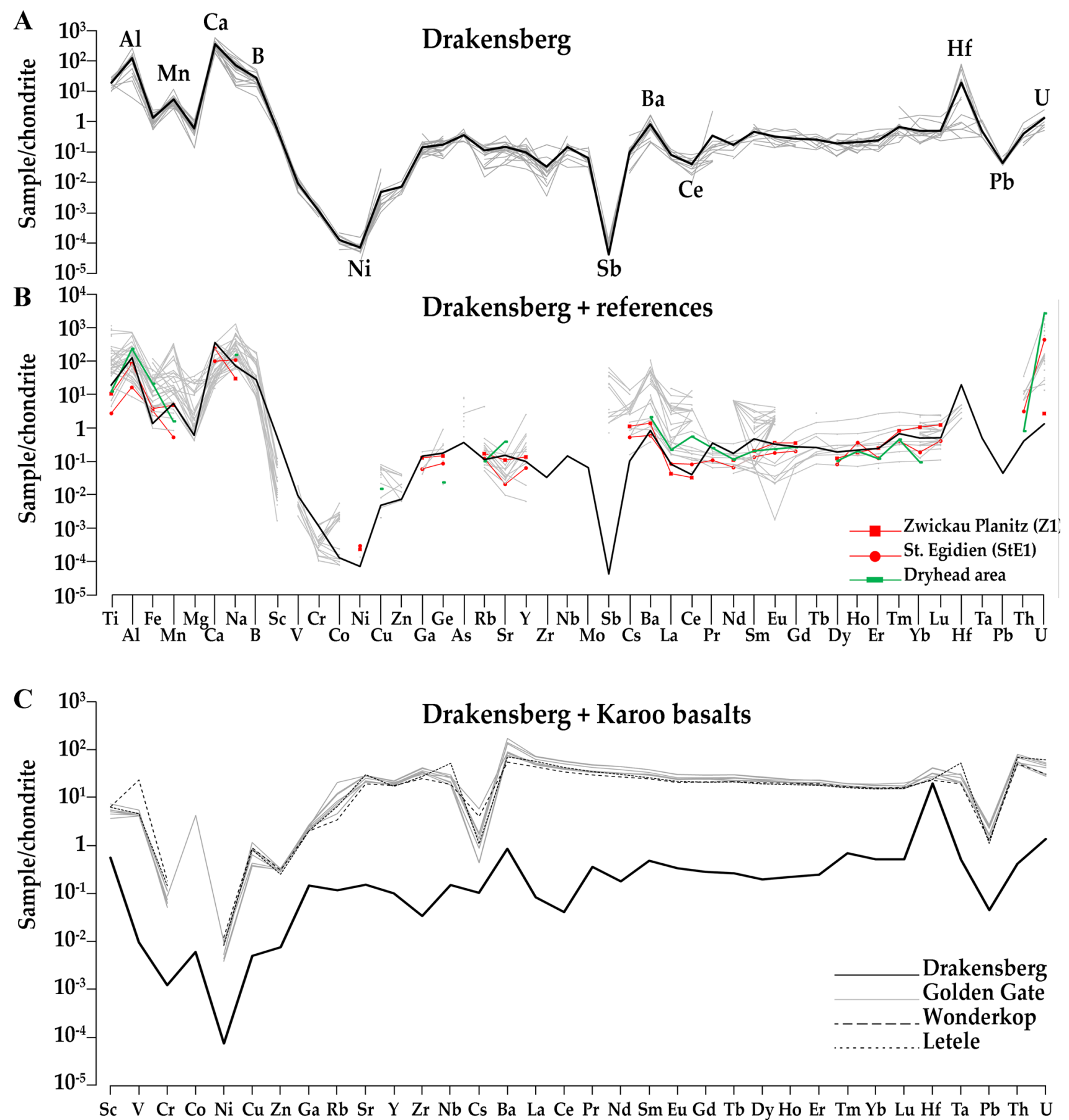

Fig. 5 Concentrations of Drakensberg agates normalised to the chondrite (McDonough and Sun 1995). a Grey lines indicate each sample while the black thick line indicates the average value obtained for Drakensberg samples. b Grey, red and green lines indicate reference samples and the black thick line indicates the average value obtained for Drakensberg samples. Comparison with references data includes a total of 40 measurements performed on both chalcedonies and agates from Nova Paka and Frýdštejn in the Czech Republic, Gröppendorf, Lauterbach and Idar-Oberstein in Germany, Montrose and Ardownie Quarry in the UK, the Sarusa Mine in Namibia, Agate Island and Agate Point in Canada, Chihuahua in Mexico, Rio grande Do Sul in Brazil (Götze et al. 2001, reviewing data from McCrank et al. 1981; Fallick et al. 1985, 1987; Blankenburg 1988; Haake and Holzhey
1989; Harris 1989; Beer 1992; Cross 1996; Schmitt-Riegraf 1996), Chemnitz, Chemnitz-Altendorf, Hohenstein Ernstthal, St. Egidien, Zwickau-Planitz in Germany (Götze et al. 2016; samples Z1 and StE1 provided in Table 5), Nowy Kościoł in Poland (Möckel et al. 2009) and the Montana Bighorn district in the USA (Götze et al. 2009). c Grey lines indicate basalts analyses while the black thick line indicates the average value obtained for Drakensberg samples. Comparison with different Units of the Barkly east Formation (Karoo basalts) have been made with a total of 15 measurements provided by Luttinen (2018): OXB-61, MLP-183, LTW-42 (Wonderkop), LTW-47, OXB-63, LTW-50A, OXB-65 (Letele), OXB-66, LWT-49, OXB-64, MLP-184, MLP-185, MLP-186 (Golden Gate) 
Table 1 Whole-rock $\delta^{18} \mathrm{O}$ values were determined for a total of 18 samples from both the Drakensberg Group and Windsorton

\begin{tabular}{llc}
\hline & $\begin{array}{l}\delta^{18} \mathrm{O} \\
(\% \text { VSMOW })\end{array}$ & $T_{\text {oceanic water }}$ \\
\hline Drakensberg group & & \\
D19 & 16.0 & 143 \\
D4 & 20.0 & 105 \\
D10 & 20.1 & 104 \\
D1 & 20.2 & 104 \\
D15 & 20.5 & 101 \\
D8 & 21.2 & 96 \\
Windsorton & & \\
Win9 & 17.5 & 128 \\
Win1 & 18.0 & 123 \\
Win11 & 18.4 & 119 \\
Win5 & 18.7 & 116 \\
Win12 & 18.8 & 115 \\
Win4 & 18.8 & 115 \\
Win7 & 19.0 & 114 \\
Win13 & 19.1 & 113 \\
Win2 & 20.9 & 98 \\
Win6 & 22.1 & 90 \\
Win3 & 23.1 & 82 \\
Win14 & 23.3 & \\
\hline
\end{tabular}

Temperature estimation has been calculated based on quartz- $\mathrm{H}_{2} \mathrm{O}$ equilibrium fractionation equation of Matsuhisa et al. (1979) and using a $\delta^{18} \mathrm{O}$ value of water of oceanic water of $\pm 0 \%$ o

software package GLITTER (van Achterbergh et al. 2001) and using NIST SRM 610 and ${ }^{29} \mathrm{Si}$ as external and internal standards, respectively.

Furthermore, to further constrain the origin, a total of 18 samples from both the Drakensberg Group (D1,4,8,10,15,19) and Windsorton (Win 1-7, 9, 11-14) were analyzed for their oxygen isotope composition $\left({ }^{16} \mathrm{O},{ }^{18} \mathrm{O}\right)$. The samples were measured at the University of Lausanne, using a method similar to that described in Vennemann et al. (2001). Between 0.5 and $2 \mathrm{mg}$ of sample was loaded onto a small Pt-sample holder and pumped out to a vacuum of about $10^{-6}$ mbar. After prefluorination in the sample chamber overnight, the samples were heated with a $\mathrm{CO}_{2}$-laser in 50 mbars of pure $\mathrm{F}_{2}$. Excess $\mathrm{F}_{2}$ is separated from the $\mathrm{O}_{2}$ produced by conversion to $\mathrm{Cl}_{2}$ using $\mathrm{KCl}$ held at $150{ }^{\circ} \mathrm{C}$. The extracted $\mathrm{O}_{2}$ is collected on a molecular sieve (5A) and subsequently expanded into the inlet of a Finnigan MAT 253 isotope ratio mass spectrometer. Oxygen isotope compositions are given in the standard $\delta$-notation, expressed relative to VSMOW in permil $(\% o)$. Replicate oxygen isotope analyses of the in-house standard used (Ls-1 quartz; $n=x$ ) had an average precision of $\pm 0.1 \%$ for $\delta^{18} \mathrm{O}(n=6)$. The accuracy of $\delta^{18} \mathrm{O}$ values is better than $0.2 \%$ compared to accepted $\delta^{18} \mathrm{O}$ values for NBS-28 of $9.64 \%$.

Lastly, to compare the geochemical composition to the textural features of the Windsorton agates, polished thin sections $(30 \mu \mathrm{m})$ of a selected group of samples (nos. 1-9) were investigated by polarizing light microscopy. Length slow (with slow ray parallel to the elongation, i.e., positive) and length fast (with fast ray parallel to the elongation, i.e., negative) chalcedony was further distinguished, using the $550 \mathrm{~nm}$ gypsum plate (compensator).

\section{Results}

\section{Site A: Drakensberg group}

LA-ICP-MS. The results obtained on the 21 Drakensberg samples (Fig. 2; Supplementary Table 1) show the typical composition of chalcedony and agate (see e.g., Merino et al. 1995; Götze et al. 2001; Möckel and Götze 2007; Möckel et al. 2009; Götze et al. 2009, 2016) with small concentrations of elements other than silica (on average $99.8 \mathrm{wt} \% \pm 0.07)$. Among chalcedonies, $\mathrm{SiO}_{2}$ contents are particularly low in sample D7 and, excluding this sample, show a marked tendency to decrease with the increase of $\mathrm{Al}, \mathrm{Na}, \mathrm{K}, \mathrm{Mn}, \mathrm{Rb}, \mathrm{Sr}$ and Ba (Supplementary Fig. 1A-F). $\mathrm{Na}, \mathrm{Al}, \mathrm{K}, \mathrm{Rb}, \mathrm{Ba}$ and $\mathrm{Sr}$ contents are weakly correlated, as well as Mn and B (Fig. 3a-f), conversely, Mg, Ti, Fe, V, Cr, $\mathrm{Ni}, \mathrm{Cu}, \mathrm{Zn}$ and $\mathrm{Ge}$ contents are not linearly correlated with any of the other measured elements. Among agates, Al, Na and $\mathrm{Rb}$ and $\mathrm{Sr}$ and $\mathrm{Ba}$ show similar trends within each single sample (Fig. 4a). $\mathrm{SiO}_{2}$ pattern is similar to that of $\mathrm{Mn}, \mathrm{Ga}$ and $\mathrm{Y}$ in $\mathrm{D} 4$, to none in both $\mathrm{D} 17$ and 19 while it is opposed to the trend of $\mathrm{Al}, \mathrm{Fe}, \mathrm{Na}, \mathrm{B}, \mathrm{Ge}, \mathrm{Rb}, \mathrm{Sr}, \mathrm{Ba}$ in $\mathrm{D} 4$, to that of Ge in D17 and to none in D19.

Correlating the amount of chromophores and the agates colors (especially $\mathrm{Fe}$ and $\mathrm{Mn}$ ), a direct comparison is not straightforward, i.e., dark and light bands cannot be directly correlated to an increase/decrease of Fe or Mn contents (Fig. 4b). In detail, the light grey sample D19 shows low $\mathrm{Fe}$ content but the highest Mn contents of this group while the dark brownish samples $8,11,16,21$ and 22 show variable Mn contents (0.7/1.4 ppm) and Fe levels, ranging from 14 to 56 ppm, i.e., the lowest and the highest values of the group, respectively. The remaining dark grey samples show the entire range of $\mathrm{Fe}$ contents and $\mathrm{Mn}$ levels ranging from 0.8 to $1.8 \mathrm{ppm}$.

Concentrations normalized to those of the chondrite (Fig. 5) are comparable in $\mathrm{Ba}, \mathrm{Fe}$ and $\mathrm{Mg}$, enriched in $\mathrm{Ti}$, $\mathrm{Al}, \mathrm{Mn}, \mathrm{Ca}, \mathrm{Na}, \mathrm{B}, \mathrm{Hf}$ and $\mathrm{U}$, and depleted in all the others trace elements (esp. Ni and with LREE more depleted than HREE). Negative $\mathrm{Ce}$ and $\mathrm{Sb}$ anomalies are noteworthy. 

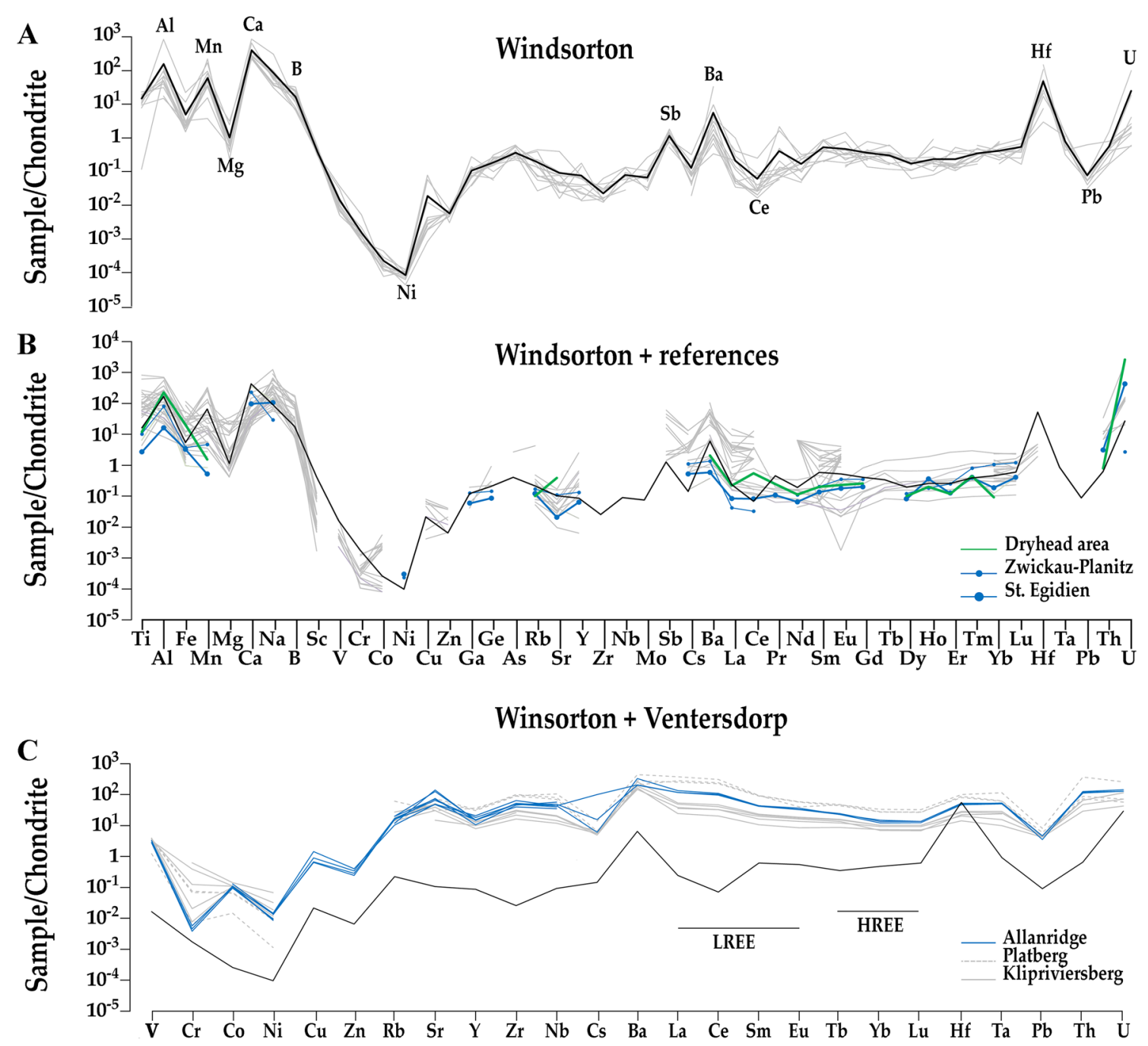

Fig. 6 Concentrations of Windsorton agates normalised to the continental chondrite (McDonough and Sun 1995). a Grey lines indicate each sample while the black thick line indicates the average value obtained for Windsorton samples. b Grey, blue and green lines indicate reference samples while the black thick line indicates the average value obtained for Windsorton samples. Comparison with references

\section{Isotopic analysis}

Determined for a total of six chalcedony samples (D1, 4, 8, 10, 15 and 19; Table 1), the whole-rock $\delta^{18} \mathrm{O}$ values have a range between 16 (sample D19) and $21.2 \%$ (sample D8), however, the majority of samples have values between 20.0 and $20.5 \%$ (D4, 10, 1 and 15), without clear differences between chalcedony (D1, 8, 10 and 15) and agate (D4 and 19). These values are rather similar to those provided by Ledevin (2013) for South African Precambrian chert (3432/3416 Ma) from Komati River $\left(\delta^{18} \mathrm{O}\right.$ of $16.8-19.4 \%$ ) and Buck Reef $\left(\delta^{18} \mathrm{O} 20.0-20.6 \%\right.$ ). data includes the same 40 measurements previously used (see Fig. 5). c Grey and blue lines indicate basalts analyses while the black thick line indicates the average value obtained for Windsorton samples. Comparison with different Units of the Ventersdorp Formation have been made with a total of 15 measurements provided by Keyser 1988 (Table 5.2) and Crow and Condie 1988 (Table III)

\section{Site B: Vaal River alluvial gravels at Windsorton}

LA-ICP-MS. Similar to samples of the Drakensberg Group, the results obtained on the 15 Windsorton samples (89 measurements; Supplementary Table 1) have shown the typical composition of chalcedony and agate, with small concentrations in other elements than silica (on average $99.8 \mathrm{wt} \% \pm 0.07$ ); however, Windsorton agates are compositionally more heterogeneous, both in terms of absolute values and the relationships between the various elements (Fig. 3g-1). For example, $\mathrm{SiO}_{2}$ values range between 98.3 and $99.9 \mathrm{wt} \%$ while it was limited between 99.3 and 99.9 wt\% in the Drakensberg Group samples. 

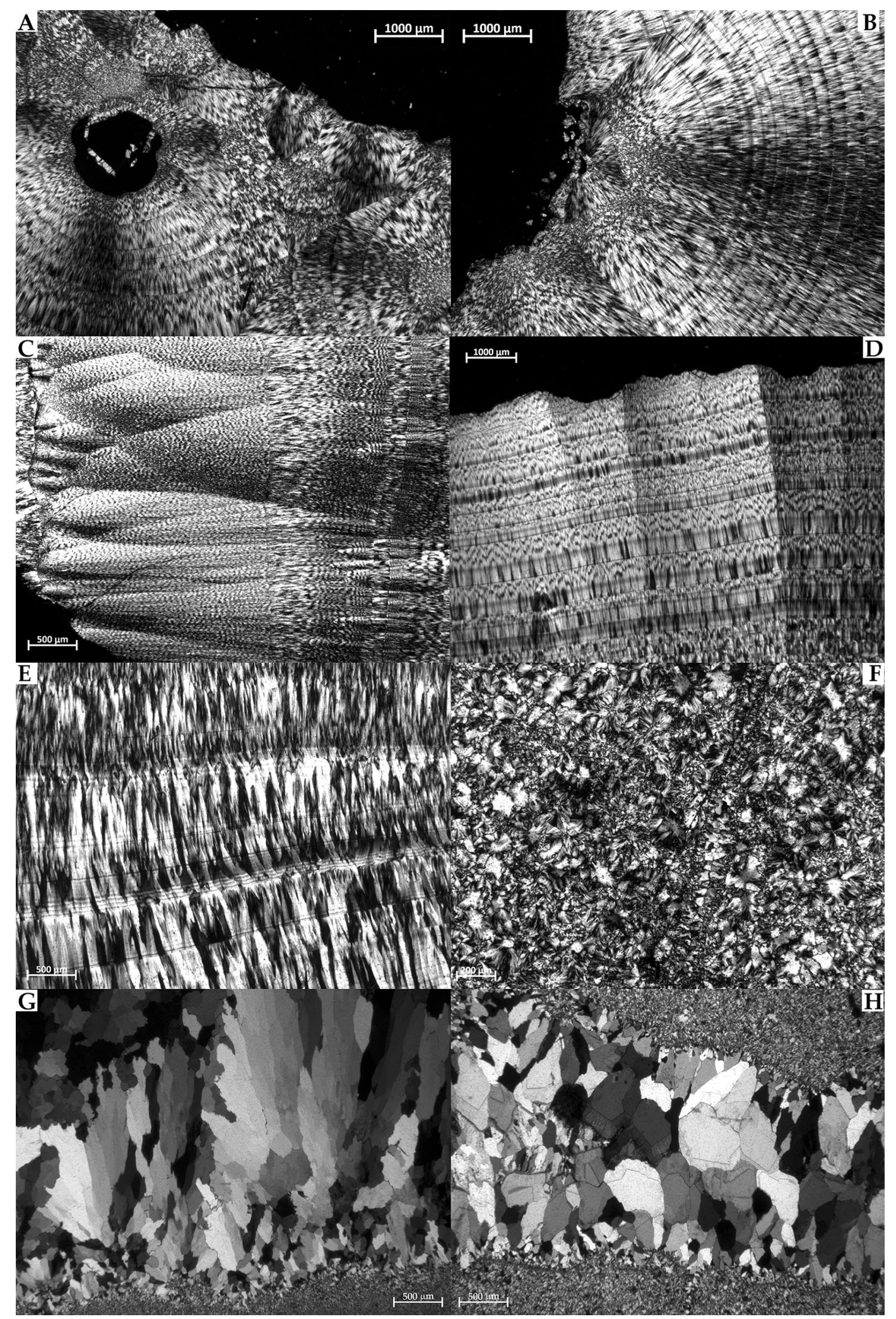

Fig. 7 Optical microscopy on selected Windsorton samples. Bands of concentric length-slow and length-fast chalcedony in samples Win1 (a) and 2 (b). Fan-shaped aggregates of spherulitic chalcedony in sample Win3 (c). Alternating bands of length-slow and length-fast chalcedony in samples Win4 (d) and Win5 (e). Aggregates of zebraic chalcedony in Win7 (f). Feathery and macrocrystalline granular quartz, respectively, in samples Win6 (g) and 7 (h) 


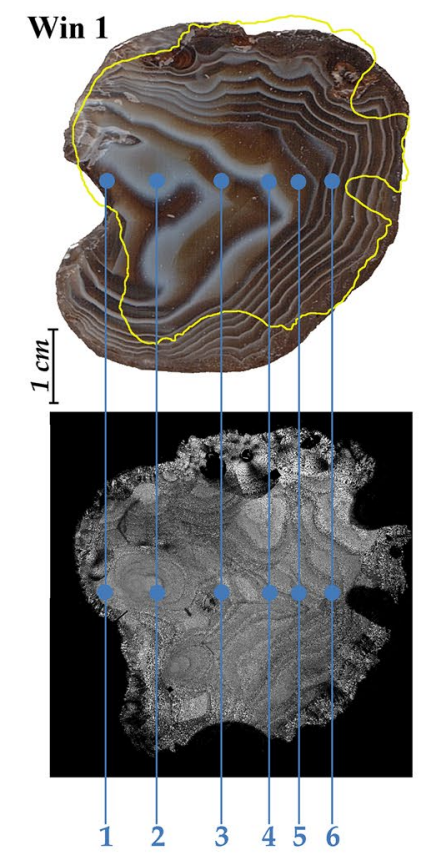

Win 1

$\mathrm{Na}$

$\operatorname{Mn}{ }_{2}^{33}$

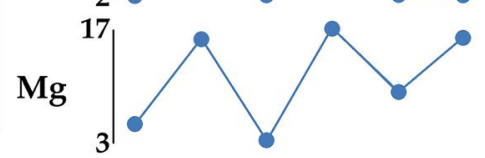

${ }_{7}^{59}$

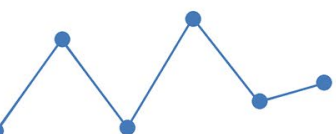

Win 2

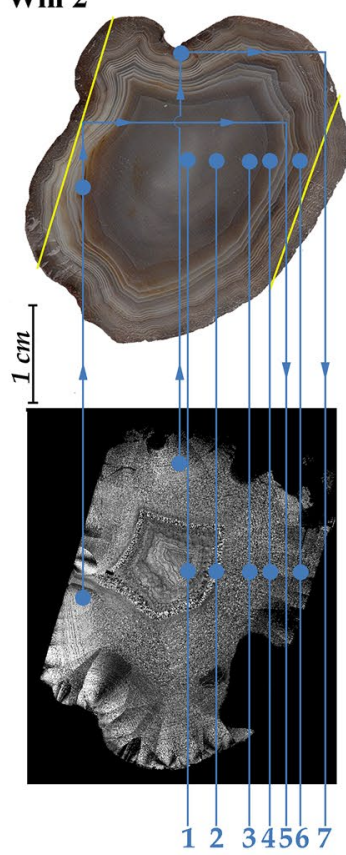

Fe<smiles>[AsH2]</smiles>

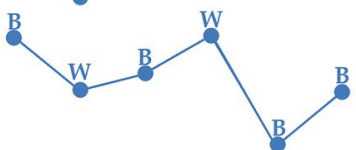

B
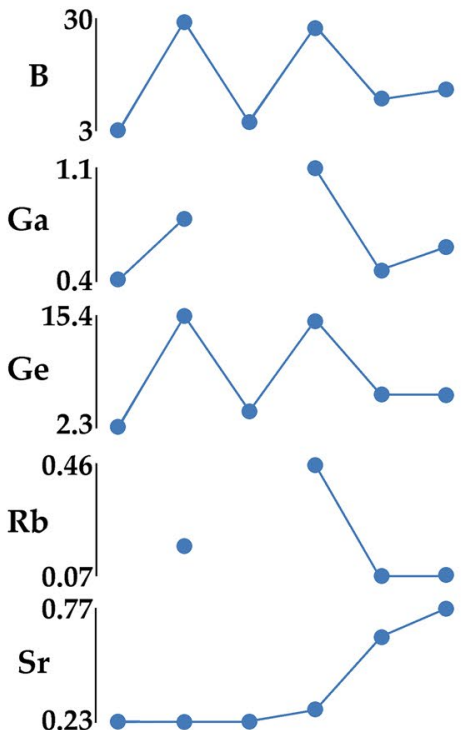

$\begin{array}{llllllllllll}\text { Win } 1-1 & 2 & 3 & 4 & 5 & 6 \text { Win2-1 } & 2 & 3 & 4 & 5 & 6 & 7\end{array}$

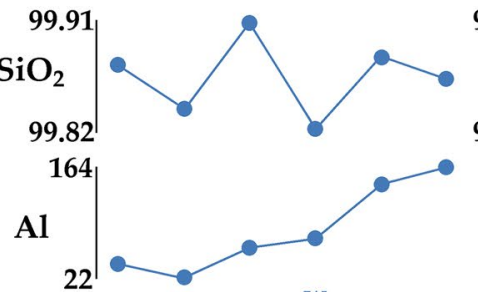

99.54
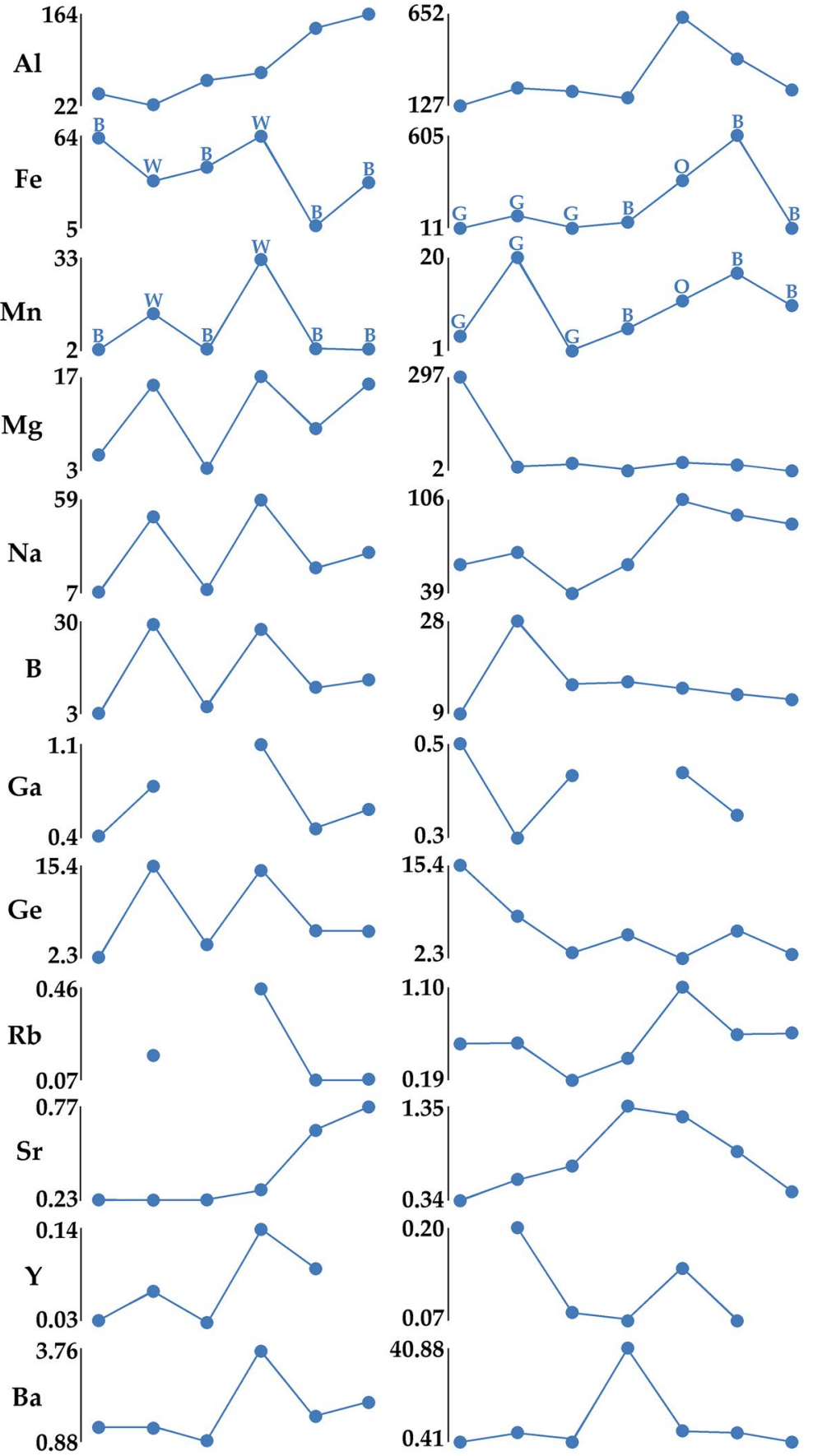

Fig. 8 Geochemical profiles on samples Win1 and 2. Both macro (scanner) and micro (optical microscopy) images have been provided per each sample. Along Fe and Mn profiles, $B$ brown, $W$ white, $G$ grey, $O$ orange. Sample Win1: From the inner to the outer rim (nos 1-6), $\mathrm{Al}$ and $\mathrm{Sr}$ increase while Fe decreases. $\mathrm{Mn}, \mathrm{Mg}, \mathrm{Na}, \mathrm{B}, \mathrm{Ga}, \mathrm{Ge}$, $\mathrm{Y}$ and $\mathrm{Ba}$ show similar oscillating patterns, opposed to $\mathrm{SiO}_{2}$ trend. Sample Win2: From the inner to the outer edge, $\mathrm{Mg}$ and $\mathrm{Ge}$ decrease.
$\mathrm{SiO}_{2}$ contents are constantly high in microgranular quartz, decrease in the zebraic chalcedony and rise again at the outer edge (thin alternating bands). The central micro-granular quartz is particularly poor in $\mathrm{Al}, \mathrm{Fe}, \mathrm{Mn}, \mathrm{B}, \mathrm{Sr}$ and $\mathrm{Ba}$ and particularly rich in $\mathrm{Mg}, \mathrm{Ga}$ and $\mathrm{Ge} . \mathrm{Al}$, $\mathrm{Na}, \mathrm{Rb}$ and $\mathrm{Y}$ trends are comparable and inverse to $\mathrm{SiO}_{2}$; similarly $\mathrm{Fe}, \mathrm{Mn}$ and $\mathrm{B}$ and $\mathrm{Sr}$ and $\mathrm{Ba}$ show similar patterns 


\section{Win 3}

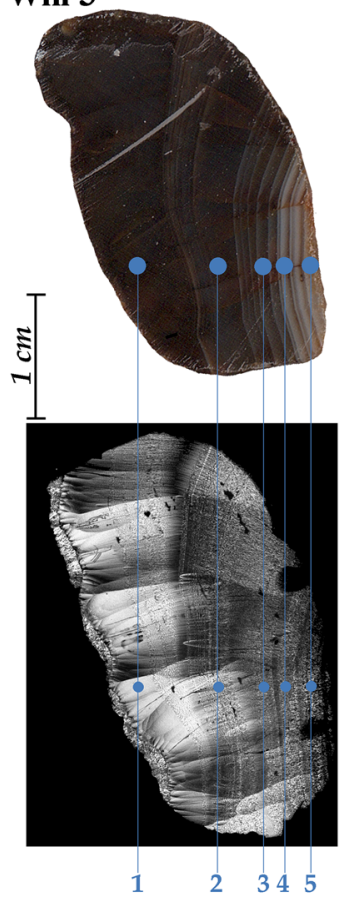

Win 4

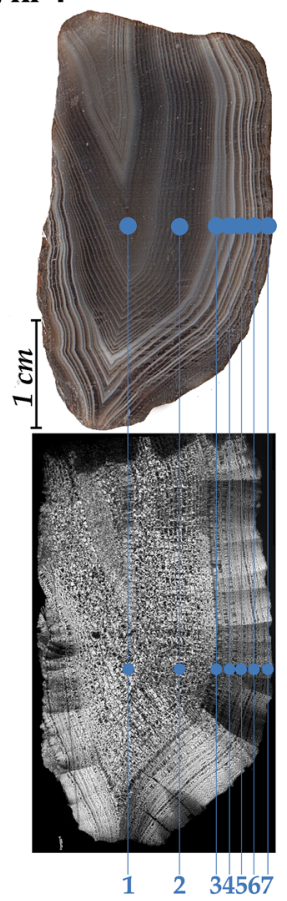

$\begin{array}{llllllllllll}\text { Win3- } 1 & 2 & 3 & 4 & 5 & \text { Win } 4-1 & 2 & 3 & 4 & 5 & 6 & 7\end{array}$
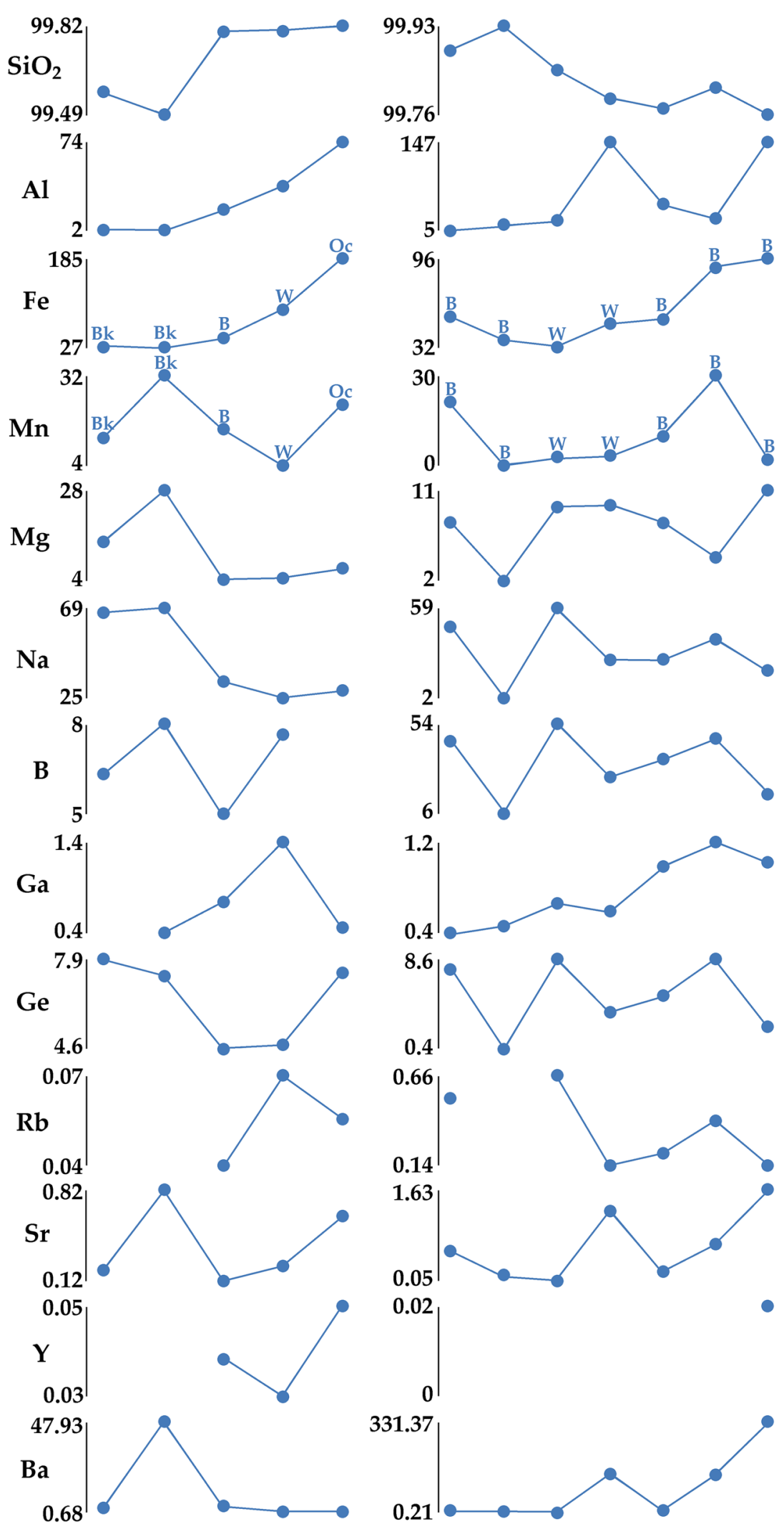
4Fig. 9 Geochemical profiles on samples Win3 and 4. Both macro (scanner) and micro (optical microscopy) images have been provided per each sample. Along $\mathrm{Fe}$ and $\mathrm{Mn}$ profiles, $B k$ blackish, $B$ brown, $W$ white, $O c$ ochre. Sample Win3: From the outer to the inner rim, Al and $\mathrm{Fe}$ constantly increase while $\mathrm{Mg}$ and $\mathrm{Na}$ decrease. Similar elements trends are observed in large fan shaped or in thin alternating bands. Partially similar patterns are shown by $\mathrm{Mn}, \mathrm{Mg}, \mathrm{Na}, \mathrm{Sr}$ and $\mathrm{Ba}$, inverse to $\mathrm{SiO}_{2}$ trend and by $\mathrm{Al}$ and Fe. Sample Win4: From the inner zebraic and macroscopically darker area to the outer edge, characterised by thin alternating bands of a grey lighter colour, $\mathrm{SiO}_{2}$ decreases while $\mathrm{Fe}, \mathrm{Ga}, \mathrm{Sr}$ and $\mathrm{Ba}$ basically increase. Similar patterns are shown by (a) $\mathrm{Al}, \mathrm{Sr}$ and $\mathrm{Ba}$; (b) $\mathrm{Mn}, \mathrm{Na}, \mathrm{B}$ and $\mathrm{Ge}$; and (c) $\mathrm{Ga}$ and $\mathrm{Fe}$

Moreover, the element contents vary independently from one to the other (e.g., $\mathrm{SiO}_{2}$ does not show any correlation with respect to $\mathrm{Al}$ or $\mathrm{Na}$ or $\mathrm{Mn}$ or $\mathrm{Rb}$ or $\mathrm{Sr}$ contents; Supplementary Fig. 1G-L).

Bulk geochemical concentrations normalized to those of the chondrite (Fig. 6) are comparable in $\mathrm{Mg}$ and $\mathrm{Sb}$, enriched in $\mathrm{Ti}, \mathrm{Al}, \mathrm{Fe}, \mathrm{Mn}, \mathrm{Mg}, \mathrm{Ca}, \mathrm{Na}, \mathrm{B}, \mathrm{Ba}, \mathrm{Hf}$ and $\mathrm{U}$, depleted in all the others trace elements (with LREE slightly more depleted than HREE). Ce anomaly is negative in this case also.

\section{Isotopic analysis}

The $\delta^{18} \mathrm{O}$ values were determined for a total of 12 samples from this group (Win 1-7,9,11-14; Table 1). These Windsorton samples have values in a range from 17.5.0 to $19.1 \%$. Four samples (Win2, 3, 6 and 14) have higher values of between 20.9 and $23.3 \%$. These values are rather similar to those provided by Ledevin (2013) for South African Precambrian (3260 Ma) chert from Barite Valley $\left(\delta^{18} \mathrm{O}\right.$ of $21.0-23.7 \%$ ).

\section{Optical microscopy}

Mineralogical investigations on a selected set of samples (samples Win 1-7 and 9) have clearly demonstrated that all the agates are made up by fibrous microcrystalline and nanocrystalline chalcedony, as well as by macrocrystalline granular quartz. The microtextures are various, ranging from monocentric wall-lining (e.g., sample no. 2), to polycentric wall-lining (e.g., sample no. 1) and horizontally banded agates (e.g., sample no. 6). In samples nos. 1 and 2, respectively, polycentric and monocentric, bands of concentric length-slow and length-fast chalcedony are observed along the outermost layers (Fig. 7a, b), while zebraic chalcedony to micro-granular quartz fill the inner layers to the centre/s.

In samples nos. 3, 5 and 9, fan-shaped aggregates of spherulitic chalcedony are common in the outermost layers (Fig. 7c) while thin bands of length-slow and length-fast chalcedony alternate towards the centre (Fig. 7d). Sample
Win 4 shows thin alternating bands only, with a reduction in the thickness of the bands from the outside to the inside. In samples Win6 and 7, aggregates of zebraic chalcedony (prevalent in sample no. 7) constitute the outer layers while feathery (Fig. 7g) or macrocrystalline granular (Fig. 7h) quartz fills the innermost cavity.

Optical microscopy results combined with LA-ICP-MS data. Textural differences can be correlated to compositional differences (Figs. 8, 9, 10 and 11; Supplementary Figs. 2 and 3) in samples Win3-4 and 9. Large fan-shaped areas and thin alternating bands are characterized by relatively lower (99.5-7 wt\%) and higher (99.8-99.9 wt\%) $\mathrm{SiO}_{2}$, respectively. Lower $\mathrm{SiO}_{2}$ is counterbalanced by a constant increase of $\mathrm{Mg}$ and $\mathrm{Na}$ levels (also $\mathrm{Al}$ in Win4 and 9). In sample Win2, this relationship is not clearly observed, however, the composition of the various types of chalcedony is distinguishable, type by type. Similarly, in sample Win7, micro granular quartz and macroquartz are clearly distinguished by lower and higher $\mathrm{SiO}_{2}$ contents, respectively. In sample Win9, thin alternating bands have relatively higher $\mathrm{SiO}_{2}$ and lower $\mathrm{Al}$, $\mathrm{Fe}, \mathrm{Mn}, \mathrm{Mg}, \mathrm{Sr}, \mathrm{Ba}$ and, to a lesser extent, $\mathrm{Na}$ and $\mathrm{Rb}$ with respect to wide concentric bands. Lastly, it can be noted that fan-shaped and zebraic chalcedony are compositionally more homogeneous than alternating bands (esp. in Win3, Win4 and to a lesser extent Win5).

From the inner to the outer rims, element increase/ decrease varies sample by sample. For instance, $\mathrm{Al}$ increases in sample Win1 while decreases in sample Win3. Element trends are sample-specific, however, $\mathrm{Al}, \mathrm{Ba}$ and $\mathrm{Sr}$ generally show similar trends, inverse to that of $\mathrm{SiO}_{2}$. Lastly, the variability of $\mathrm{Fe}$ amounts cannot be correlated to the light or dark colors of the bands in the geochemical profiles of samples Win1, 4, 5, 7, 9, 10, 12, 13, 14 and 15. Conversely, high $\mathrm{Fe}$ amounts characterize the ochre bands (not the blackish ones) of samples Win3 and 6 and, together with high amounts of $\mathrm{Mn}, \mathrm{Al}, \mathrm{Ga}$ and $\mathrm{Sr}$, the orange bands of sample Win11. Regarding Mn, a relation between the variability of its contents and the light or dark colors of the agates is lacking in samples Win3, 4, 7, 9, 10, 12, 13, 14 and 15. However, in Win 1 and 2, high Mn contents correspond to white or light colors while low Mn contents correspond to brown areas. In Win 3 and 6, high Mn contents have been found in blackish and brown spots. Similarly, a direct correlation between a specific color and the abundance of the chromophores is rarely found even if considering the average values per samples (Fig. 4c). 


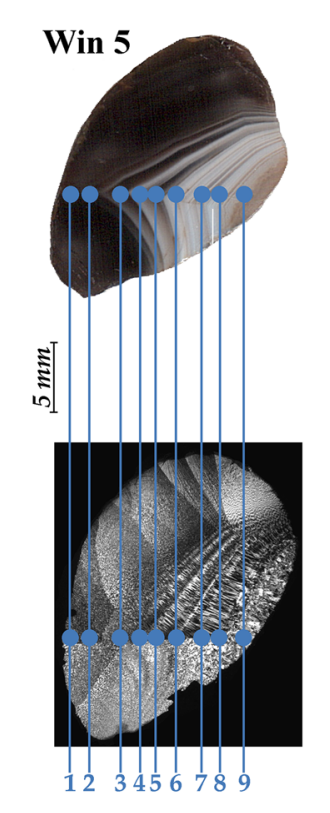

$\begin{array}{lllllllllllllll}\text { Win5 } 1 & 2 & 3 & 4 & 5 & 6 & 7 & 8 & 9 \text { Win6 } 1 & 2 & 3 & 4 & 5 & 6 & 7\end{array}$
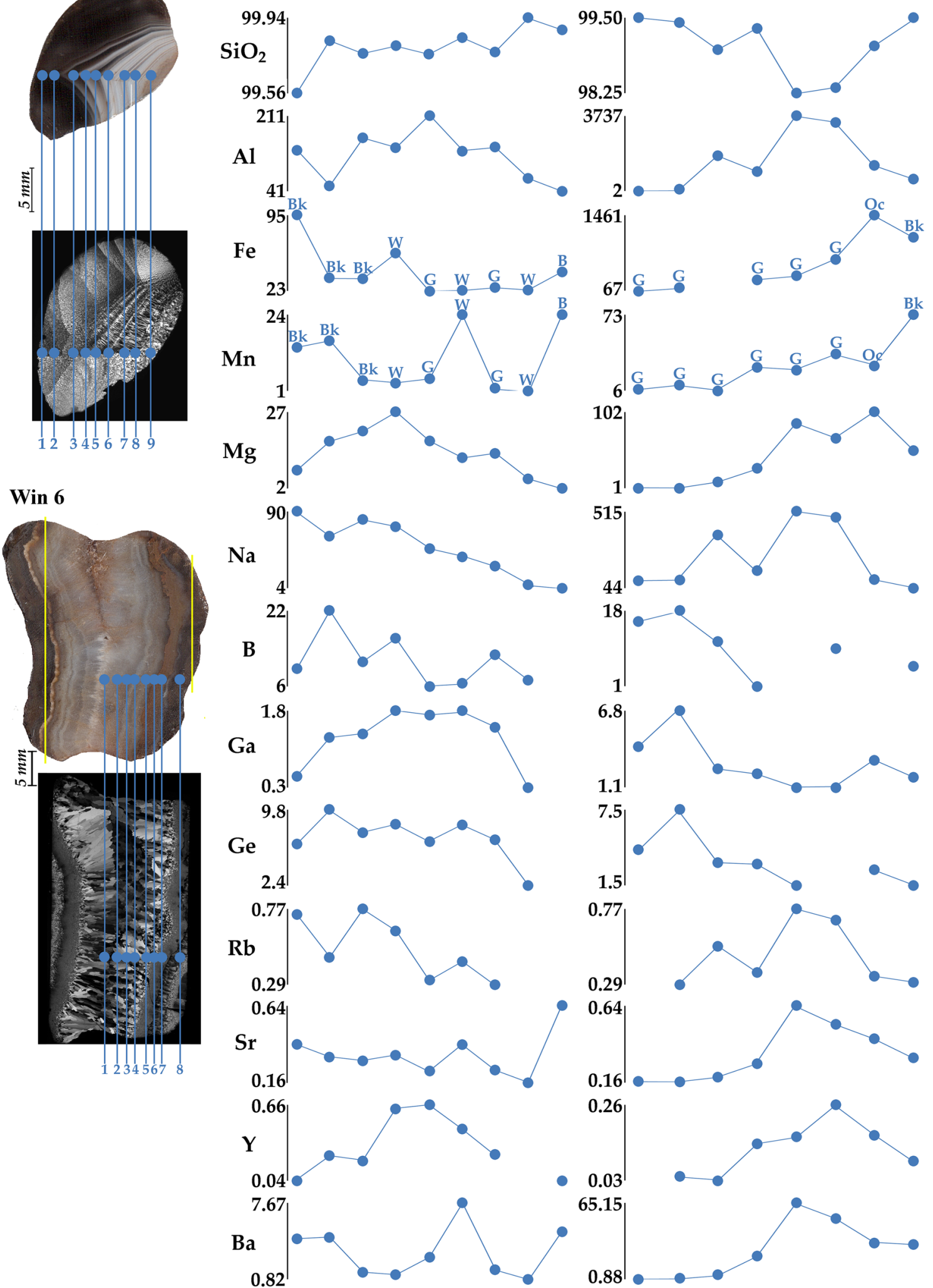
4Fig. 10 Geochemical profiles on samples Win5 and 6. Both macro (scanner) and micro (optical microscopy) images have been provided per each sample. Along $\mathrm{Fe}$ and $\mathrm{Mn}$ profiles, $B k$ blackish, $G$ grey, $B$ brown, $W$ white, $O c$ ochre. Sample Win5: From the outer dark fan shaped areas to the inner light and thin alternating bands, $\mathrm{SiO}_{2}$ increases while $\mathrm{Na}$ and, less regularly, $\mathrm{B}, \mathrm{Ge}$ and $\mathrm{Rb}$ decrease; conversely, $\mathrm{Al}, \mathrm{Mg}, \mathrm{Ga}$ and $\mathrm{Y}$ increase up to central measurements and then decrease. Similar patterns are also shown by $\mathrm{Mn}, \mathrm{Sr}$ and $\mathrm{Ba}$ while Ni (not shown) and Al trends are inverse. Sample Win6: From the inner feathery to central zebraic and outer microcrystalline granular quartz, $\mathrm{Fe}, \mathrm{Mn}$ and $\mathrm{Mg}$ while $\mathrm{Ga}, \mathrm{Ge}, \mathrm{Cu}$ and $\mathrm{Ni}$ (the latter two not shown) decrease. $\mathrm{Al}, \mathrm{Na}, \mathrm{Rb}, \mathrm{Sr}, \mathrm{Y}$ and $\mathrm{Ba}$ show comparable patterns, inverse to $\mathrm{SiO}_{2}$

\section{Discussion}

Despite the larger set of samples analyzed from the Drakensberg Group (i.e., both chalcedonies and agates), they are compositionally more homogeneous compared to those from Windsorton. Geochemical analyses enucleated a single outlier in the Drakensberg group (sample D7) while every Windsorton sample presents peculiar characteristics (esp. Win6, followed by Win2, 3, 4, 7, 13 and 15).

On average, Windsorton agates are enriched in most minor and trace elements ( $\mathrm{Ti}, \mathrm{Fe}, \mathrm{Mn}, \mathrm{Mg}, \mathrm{V}, \mathrm{Cr}, \mathrm{Co}, \mathrm{Ni}$, $\mathrm{Cu}, \mathrm{Ge}, \mathrm{As}, \mathrm{Rb}, \mathrm{Sr}, \mathrm{Y}, \mathrm{Zr}, \mathrm{Sb}, \mathrm{Ba}, \mathrm{La}, \mathrm{Ce}, \mathrm{Pr}, \mathrm{Nd}, \mathrm{Sm}, \mathrm{Eu}$, $\mathrm{Gd}, \mathrm{Tb}, \mathrm{Dy}, \mathrm{Ho}, \mathrm{Er}, \mathrm{Yb}, \mathrm{Lu}, \mathrm{Hf}, \mathrm{Pb}, \mathrm{Th}, \mathrm{U})$ with respect to the Drakensberg samples.

To understand which processes have led to those differentiations, numerous working hypotheses have been considered. In the first place, the composition of the tholeiitic basaltic-andesitic lavas of the Allanridge Formation (Pniel Group, Ventersdorp Supergroup) has been compared with that of the Windsorton agates and the composition of the tholeiitic basaltic-andesitic lavas of the Golden Gate Unit (Barkly East Formation, Drakensberg Group) at Clarens has been compared with that of the Drakensberg chalcedonies and agates.

Major elements composition of both host rocks is very similar (Fig. 12a), as well as their Chemical Index of Alteration (CIA), which point to a mild weathering and limited alteration. These conditions would lead to the formation of similar agates, however, with respect to the host rocks, Windsorton agates are relatively less depleted in $\mathrm{Fe}, \mathrm{Mn}, \mathrm{Mg}$ and $\mathrm{Ca}$ compared to the Drakensberg chalcedonies. Among minor elements contents (Fig. 12B), V, $\mathrm{Co}, \mathrm{Ni}, \mathrm{Cu}, \mathrm{Zn}, \mathrm{Ga}, \mathrm{Cs}$ and $\mathrm{Ba}$ display similar trend in both host rocks and chalcedonies/agates while $\mathrm{Y}, \mathrm{Zr}$ and $\mathrm{Nb}$ are reversed; moreover, in Allanridge lavas and Windsorton agates, $\mathrm{Cr}$ absolute content is very similar while the $\mathrm{Rb}-\mathrm{Sr}$ trends are reversed. REE patterns (Fig. 12b) are overall decreasing from LREE to HREE in host rocks while increasing in chalcedonies/agates and a Ce negative anomaly is clearly observed in chalcedonies/agates while absent in the host rocks. Lastly, a negative $\mathrm{Pb}$ anomaly is typical of both host rocks and chalcedonies/agates, while a positive Hf anomaly is present in chalcedonies/agates, only. The marked increase of $U$ contents, with respect to Th (relatively immobile), further characterizes chalcedonies and agates from both sites and it may be easily explained considering that $U$ can be released and accumulated during alteration processes.

As a result of this comparison, it is possible to assert that the compositional differences observed in chalcedonies and agates cannot be attributed to the composition of the host rocks, therefore, two different possibilities have been then considered: (1) that the differences occurred during their formation (e.g., fluid circulation) or (2) at a later stage (e.g., weathering). While assuming that both processes could have influenced the composition of the investigated samples, main arguments are in support of the first hypothesis:

(a) The difference in $\mathrm{Mn}$ and, to a lesser extent, in $\mathrm{Fe}$,i.e., of two elements that are easily transported and deposited through oxidation-cannot be directly related to the composition of the host-rocks but rather to a different efficiency of the metasomatism (with $\mathrm{H}^{+}$displacing the cations-e.g., $\mathrm{Fe}^{2+}, \mathrm{Mn}^{2+}, \mathrm{Cu}^{2+}$ and $\mathrm{Zn}^{2+}-$ from the $\mathrm{Fe}-\mathrm{Mg}$ and aluminosilicate rock-forming minerals) in the two different geographic areas.

(b) The high amounts of Ge, $\mathrm{U}$ and $\mathrm{B}$ can be explained if considering the possible interaction of volatile fluids (HF), which lead to the volatile transport of $\mathrm{SiF}_{4}$, as well as of compounds such as $\mathrm{BF}_{3}, \mathrm{GeF}_{4}$ and $\mathrm{UO}_{2} \mathrm{~F}_{2}$ (this chemical transport reaction is fully discussed in Götze et al. 2012).

(c) The coherent or opposite behavior of specific elements in chalcedonies/agates with respect to their host-rocks may indicate that $\mathrm{H}_{2} \mathrm{~S}$-bearing fluids have also played a role (e.g., reacting with $\mathrm{H}_{2} \mathrm{O}$ to form sulphuric acid), given that acidic conditions favorably mobilize some specific elements only (e.g., V, Sr, Zr and LREE consistently depleted in Drakensberg samples).

(d) The pronounced positive Hf anomaly-also measured in several reference data-may be due to Hf solubility in siliceous melts, given that its resistant nature limits its concentration in water.

(e) The HREE enrichment (with respect to LREE) is frequently observed in agates and it is generally explained as an overprinting of the primary composition by "the preferred complexation of released HREE by carbonate- and F-complexes during the alteration and transport processes" (see e.g., Götze et al. 2016 also quoting Wood 1990). Similar processes are involved in Ba mobilization as sulphate and carbonate.

(f) Based on isotopic measurements, these chalcedonies and agates come from different localities and were likely formed at different times. One possible explana- 


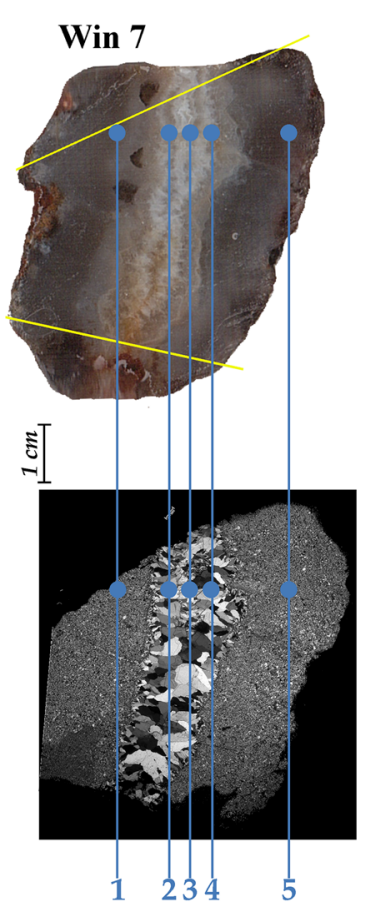

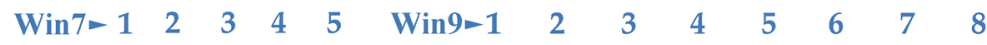
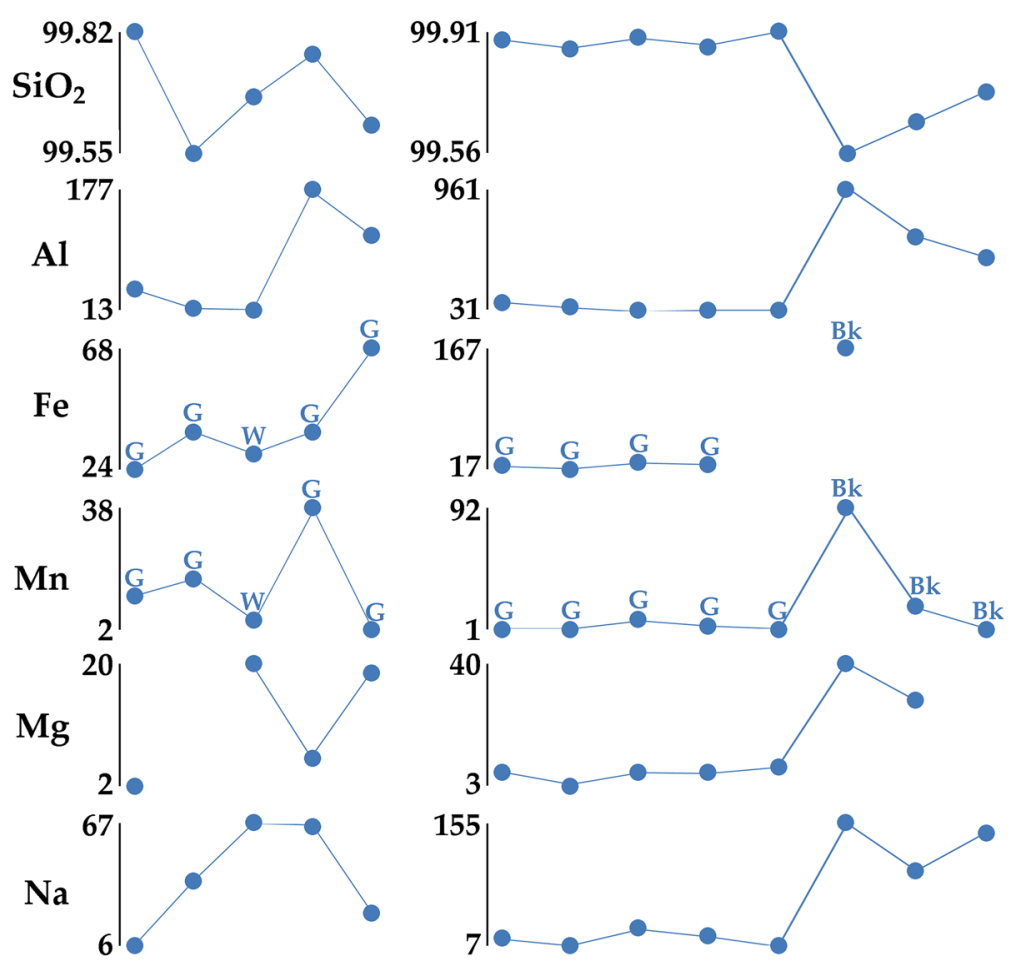

Win 9

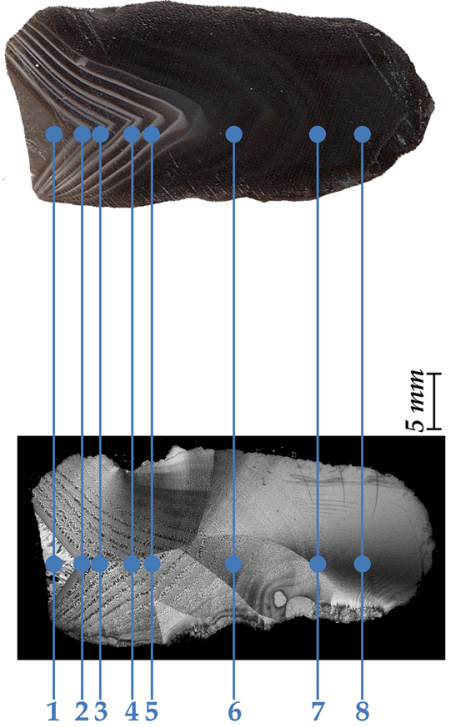

B
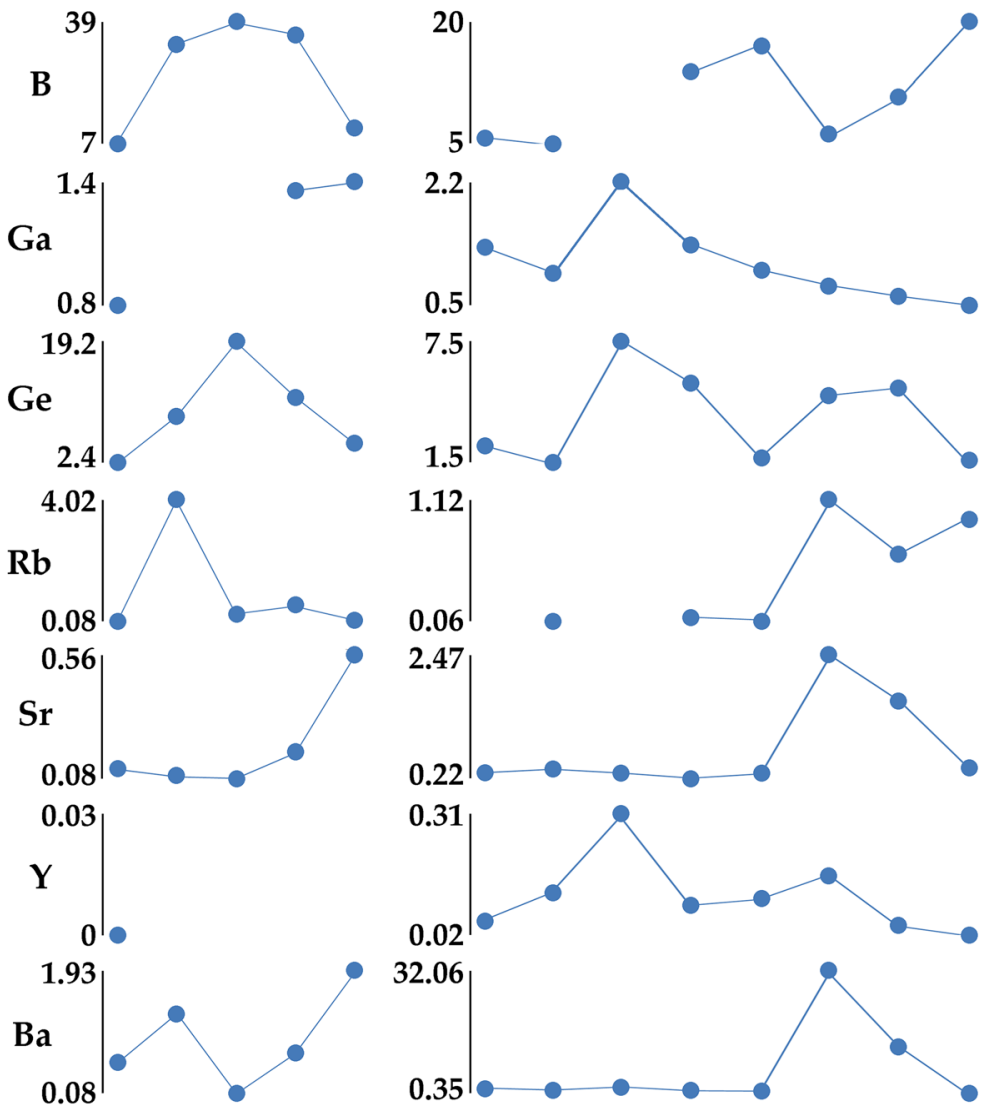
4Fig. 11 Geochemical profiles on samples Win7 and 9. Both macro (scanner) and micro (optical microscopy) images have been provided per each sample. Along $\mathrm{Fe}$ and $\mathrm{Mn}$ profiles, $B k$ blackish, $G$ grey, $W$ white. Sample Win7: The inner area is filled by macrocrystalline granular quartz while the edges are made of microcrystalline granular quartz. Regular trends are not evident, except for $\mathrm{Na}, \mathrm{B}, \mathrm{Ge}, \mathrm{Rb}, \mathrm{Sc}$ and $\mathrm{V}$ (the latter two not shown), which show higher levels in macrothan in micro-crystalline quartz. This sample has no chalcedony. Sample Win9: From the inner area characterised by thin alternating bands, to the outer bands of concentric length-slow and length-fast chalcedony, $\mathrm{Al}, \mathrm{Fe}, \mathrm{Mn}, \mathrm{Mg}, \mathrm{Sr}$ and $\mathrm{Ba}$ show a flat pattern until point 5 , followed by a sudden increase at no. 6 and a further decrease at nos. 7 and 8, overall inverse to the patterns of $\mathrm{Si}$ and $\mathrm{B}$. $\mathrm{Na}$ and $\mathrm{Rb}$ show similar patterns to the former ones, except at no. 8

tion for the differences would be that they are of hydrothermal origin, forming at similar temperatures in the presence of isotopically similar fluids that may even be of late magmatic origin (see Fig. 13 for comparison).

This scenario would, therefore, imply a circulation of hydrothermal fluids that, geochemically diversified diachronically/geographically in terms of $\mathrm{HF}, \mathrm{H}_{2} \mathrm{O}, \mathrm{CO}_{2}$ and $\mathrm{H}_{2} \mathrm{~S}$ contents, have variably acted on host rocks, resulting in a consequent diversification of the chalcedonies and agates.

Acidic-oxidising conditions are part of this reconstruction, as evidenced by the negative $\mathrm{Ce}$ anomaly and positive $U$ anomaly. The Ce negative anomaly is explained by the redox-sensitive behavior of this element (e.g., Liu et al. 1988; Braun et al. 1990; Bau et al. 1996; Shields and Stille 2001; Bau and Koschinsky 2009) that passes from the soluble state (trivalent) in a reducing medium, to an insoluble state (tetravalent) in an oxidizing medium. Hence, Ce anomalies are indicative of the redox conditions which were prevailing when REE were incorporated into the chalcedony/ agate and geode filling. In this case, both Windsorton agates and Drakensberg samples show negative anomalies which are indicative of oxidizing conditions, suitable for stabilizing $\mathrm{Ce}^{4+}$. The absence of slightly positive Eu anomalies of the same agates coincides with the Ce anomaly and, therefore, with the reconstruction of oxidizing conditions during agate formation. Similarly, high U amounts support the fact that $\mathrm{U}$ is more soluble in oxidizing, alkaline and carbonate-rich water than under acidic, reducing conditions. In this regard, the capacity of organic compounds to mobilize specific elements, the high amounts of B, Ge and Hf may suggests that organic material played a role, as it enhances the mobilization of B, especially in acidic conditions, thereby increasing Hf concentrations in water and complexation with Ge with the humic acid component (for Ge see Wedepohl 1978).

The extent of chemical weathering is evident at the scale of the single specimen (i.e., the higher heterogeneity of Windsorton agates with respect to the Drakensberg samples) while it does not seem to have left significant traces at the scale of the average group values. In these cases, it is, therefore, advisable to obtain a good number of samples to be sure of a representative statistic.

Finally, it is worth underlining that other factors may control the chalcedonies/agate composition. In detail, elements can be either incorporated or bound to micro-inclusions (e.g., Al), or preferentially incorporated in the structure of specific mineral phases (e.g., Al, $\mathrm{Na}, \mathrm{Rb}, \mathrm{Sr}$ and $\mathrm{Ba}$ in Drakensberg samples whose correlated trends seems due to feldspar impurities or Ge in quartz), or even preferentially present in micro-inclusions (e.g., Fe and Mn). Indeed, crystal-chemical rules generally control the distribution of REE, based on their relative differences in ionic radii and charge (ionic radii of LREE $\left(\mathrm{La}^{3+}-\mathrm{Eu}^{3+}\right)=1.18-1.07 \AA$; HREE $\left(\mathrm{Y}^{3+}\right.$ with $\left.\left.\mathrm{Gd}^{3+}-\mathrm{Lu}^{3+}\right)=1.07-0.97 \AA\right)$. As for chalcedony and agates, this "crystallographic control" is difficult to realize (REE ions seem too large to be incorporated into the structure) but, in absence of fluid-bearing micro-inclusions (which are usually enriched in REE) may explain the enrichment of small HREE rather than bigger LREE. Similarly, the relative abundance of Ge may have substituted for silicon atoms.

Furthermore, the compositional differences observed in relation to textures, may be related to the different uptakecapacity of the different textures with respect to the different atoms. In fact, as Wang and Merino (1995) clearly explained "agates are a remarkable case of textural and compositional self-organization", the latter being responsible of a selfpurification (see also Wang and Merino 1990; Merino et al. 1995). However, further analyses would be required before this reconstruction can be confirmed. Similarly, the observations made on chalcedonies/agates colors would require ad hoc insights. Indeed, several features may have played a role (e.g., crystallite size, porosity, water content, Tyndall effect, Mn amounts, etc.), although $\mathrm{Fe}$ oxidation state (blue $\mathrm{Fe}^{2+}$ ) may have contributed more than others. The current research excludes, however, the possibility that Fe amounts-absolute or in relation with manganese-have been somehow significant in coloring these agates.

\section{Conclusions}

The geochemical differences that distinguish Drakensberg chalcedonies/agates from Windsorton agates cannot be attributed to the composition of their host rocks. The tholeiitic basaltic-andesitic lavas of the Allanridge Formation (Pniel Group, Ventersdorp Supergroup) and the tholeiitic basaltic-andesitic lavas of the Golden Gate Unit (Barkly East Formation, Drakensberg Group) proved, in fact, to be very similar, also in terms of alteration degree.

Conversely, both sample sets have shown characteristic geochemical features of hydrothermal alteration and the 
oxygen isotope compositions support a relatively low temperature, hydrothermal origin for these agates. Fluids were heterogeneous and the formation of agates occurred in nonequilibrium conditions, although oxidizing conditions were most likely. Several factors coincided in modifying the conditions for both silica precipitation and deposition (different types of fluids, basic/acidic conditions, oxic/anoxic environment, element incorporation modalities, and substitutional properties of specific elements) and, particularly in relation to alluvial Windsorton agates, it appears that the interaction with organic compounds as well as the different adsorption of elements on the surfaces of the iron oxyhydroxides and clays may have played a significant role.

In contrast to what has been often described in the previous literature, a direct and clear correlation between the abundance of chromophores ( $\mathrm{Fe}$ and $\mathrm{Mn}$ ) and the color of the bands is generally absent. Among the numerous phenomena that may have contributed to coloring these chalcedonies/agates, Fe oxidation state may have played a more effective role than its absolute quantities or relative (esp. to $\mathrm{Mn})$ ratios.

To the best of our knowledge, texture-dependent compositional differences have been observed for the first time.
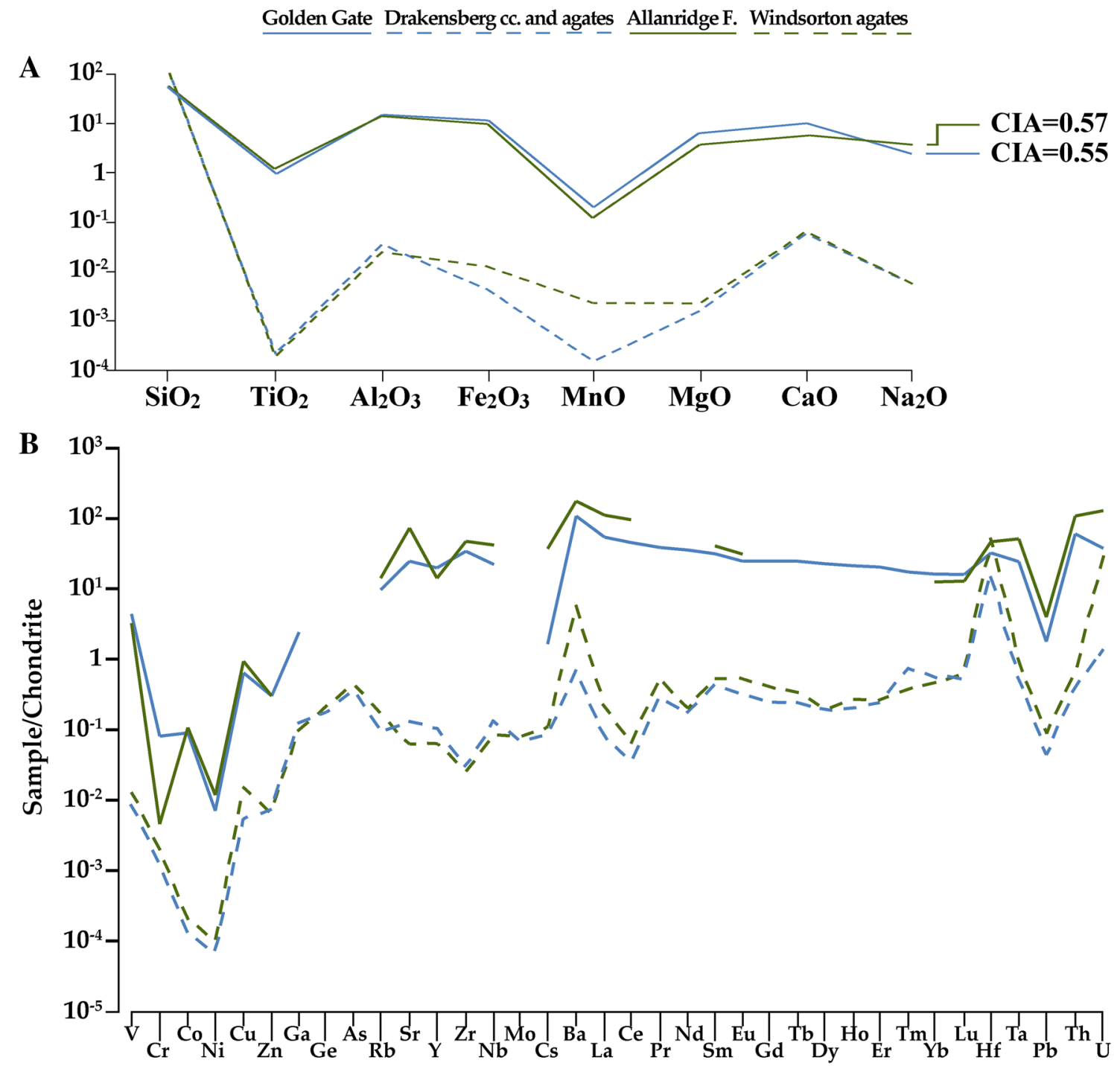

Fig. 12 a Log-ratio diagram based on log-transformed values of: Golden Gate Unit (Barkly East Formation, Lesotho Group) based on samples OXB-65, OXB-66, LWT-49, OXB-64, MLP-184, MLP-185, MLP-186, analysed by Luttinen (2018); Allanridge F. composition (Crow and Condie 1988); average values of Drakensberg chalcedonies and agates, omitting sample D7; and average values in Windsorton agates, omitting sample Win6. Chemical Index of Alteration
$(\mathrm{CIA})=\mathrm{Al}_{2} \mathrm{O}_{3} /\left(\mathrm{Al}_{2} \mathrm{O}_{3}+\mathrm{Na}_{2} \mathrm{O}+\mathrm{K}_{2} \mathrm{O}+\mathrm{CaO}\right) . \quad$ b Log-ratio diagram based on log-transformed values of: Golden Gate Unit (Barkly East Formation, Lesotho Group) based on Luttinen (2018); Allanridge F. composition (Crow and Condie 1988; Keyser 1998); average values of Drakensberg chalcedonies and agates, omitting sample D7; and average values in Windsorton agates, omitting sample Win6 


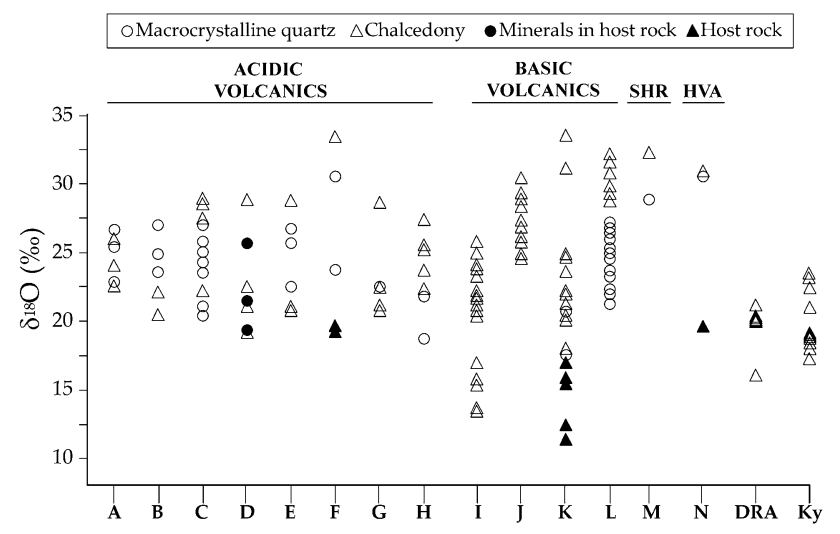

Fig. 13 Modified after Götze e al. 2016. $\delta^{18}$ OVSMOW values of the Drakensberg and Windsorton chalcedony and agate samples compared to oxygen isotope data from the literature. SRH sedimentary host rock, HVA hydrothermal vein agate; $\mathrm{A}=$ Blankenburg et. al 1982; $\mathrm{B}=$ Harris $1988 ; \mathrm{C}=$ Harris $1989 ; \mathrm{D}=$ Strauch et al. 1994; E=Holzhey 2001; F=Götze et al. 2001; G=Holzhey 2001; $\mathrm{H}=$ Götze et al. 2016; $\mathrm{I}=$ Fallick et al. $1985 ; \mathrm{J}=$ Fallick et al. 1987; $\mathrm{K}=$ Götze et al. 2001; $\mathrm{L}=$ Duarte et al. 2011; $\mathrm{M}=$ Götze et al. 2009; $\mathrm{N}=$ Götze et al. 2001

For the moment, however, the eventual relation between the chemical composition and the texture must be considered as a working hypothesis only.

Acknowledgements The authors are indebted to the two anonymous reviewers for providing insightful comments which improved the quality of our manuscript. One of us (BC) acknowledges that this research was partly funded by the NRF (National Research Foundation) and CIMERA (the DST-NRF Centre of Excellence for Integrated Mineral and Energy Resource Analysis). Any opinions, findings and conclusions or recommendations expressed are those of the author, and therefore, the NRF and CIMERA do not accept liability in regard thereto.

\section{References}

Bau M, Koschinsky A (2009) Oxidative scavenging of cerium on hydrous Fe oxide: evidence from the distribution of rare earth elements and yttrium between $\mathrm{Fe}$ ox-ides and Mn oxides in hydrogenetic ferromanganese crusts. Geochem J 43:37-47. https ://www.terrapub.co.jp/journals/GJ/pdf/4301/43010037.pdf

Bau M, Koschinsky A, Dulski P, Heinz JR (1996) Comparison of the partitioning behaviors of yttrium, rare earth elements, and titanium between hydrogenetic marine ferromanganese crusts and seawater. Geochim Cosmochim Acta 60:1709-1725. https ://doi.org/10.1016/0016-7037(96)00063-4

Beer M (1992) Achate und andere Mineralien aus den nordost-böhmischen Melaphyren. Mineralien-Welt 4:47-51 (ISSN:0939-6640)

Blankenburg H-J, Pilot J, Werner CD (1982) Erste Ergebnisse der Sauerstoffisotopenuntersuchungen an Vulkanitachaten und ihre genetische Interpretation. Chem Erde 41:213-217

Blankenburg H-J (1988) Achat. Deutscher Verlag für Grundstoffindustrie, Leipzig
Braun J-J, Pagel M, Muller J-P, Bilong P, Michard A, Guillet B (1990) Cerium anomalies in lateritic profiles. Geochim Cosmochim Acta 54:781-795. https://doi.org/10.1016/0016-7037(90)90373-S

Brown RW, Summerfield MA, Gleadow AJW (2002) Denudational history along a transect across the Drakensberg Escarpment of southern Africa derived from apatite fission track thermochronology. J Geophys Res 107(B12):1-18. https://doi. org/10.1029/2001jb000744

Brown K, Marean CW, Herries AIR, Jacobs Z, Tribolo C, Braun D, Roberts DL, Meyer MC, Bernatchez J (2009) Fire as an engineering tool of early modern Humans. Science 325:859-862. https://doi.org/10.1126/science. 1175028

Cairncross B (2004) Field guide to rocks and minerals of Southern Africa. Struik New Holland Publishing, Cape Town, p 297

Cairncross B, Dixon R (1995) Minerals of South Africa. Geological Society of South Africa, Publisher (ISBN No.0-620-19324-7)

Cairncross B, du Plessis H (2018) Stilbite and associated minerals from the Butha-Buthe district, Lesotho, southern Africa. Rocks Miner 93:306-317. https://doi.org/10.1080/00357529.2018.1454104

Clark R (2002) Fairburn Agate: gem of South Dakota. Silverwind Agates, Publ, Appleton

Cornell DH, Meintjies PG, van der Westhuizen WA, Frei D (2017) Microbeam U-Pb Zircon dating of the Makwassie Formation and underlying units in the Ventersdorp Supergroup of South Africa. S Afr J Geol 120:525-540. https://doi.org/10.25131/ gssajg.120.4.525

Cross BL (1996) The agates of Northern Mexico. Burgess International Group, Edina

Crow C, Condie KC (1988) Geochemistry and origin of late Archean volcanics from the ventersdorp supergroup, South Africa. Precambrian Res 42:19-37. https://doi.org/10.1016/03019268(88)90008-3

Duarte LC, Hartmann LA, Ronchi LH, Berner Z, Theye T, Massonne HJ (2011) Stable isotope and mineralogical investigation of the genesis of amethyst geodes in the Los Catalanes gemological district, Uruguay, southernmost Paraná volcanic province. Miner Depos 46:239-255. https://doi.org/10.1007/ s00126-010-0323-6

Duncan AR, Marsh JS (2006) The Karoo Igneous Province. In: Johnson MR, Anhaeusser CR, Thomas RJ (eds) The geology of South Africa. Geological Society of South Africa, Pretoria, pp 501-520

Duncan AR, Erlank AJ, Marsh JS (1984) Regional geochemistry of the Karoo igneous province. Spec Publ Geol Soc S Afr 13:355-388 (ISBN $079882123 \mathrm{X}$ )

Dunlevey JN, Ramluckan VR, Mitchell AA (1993) Secondary mineral zonation in the Drakensberg Basalt Formation, South Africa. S Afr J Geol 96:215-20. https://hdl.handle.net/10520/AJA1012075 0_488

Fallick AE, Jocelyn J, Donnelly T, Guy M, Behan C (1985) Origin of agates in volcanic rocks from Scotland. Nature 313:672-674. https ://doi.org/10.1038/313672a0

Fallick AE, Jocelyn J, Hamilton PJ (1987) Oxygen and hydrogen stable isotope systematics in Brazilian agates. In: Rodriguez-Clemente $\mathrm{R}$, Taedy Y (eds) Geochemistry and mineral formation in the Earth surface. Centre Nationale de la Recherche Scientifique, Paris, pp 99-117 (ISBN 840006683 9)

Frondel C (1962) The system of mineralogy. Silica minerals, vol III. Wiley, New York

Frondel C (1978) Characters of quartz fibers. Am Miner 63:17-27

Gliozzo E (2019) Variations on the silica theme: classification and provenance from Pliny to current supplies. In: Artioli G, Oberti R (eds) EMU notes in mineralogy, the contribution of mineralogy to Cultural Heritage, vol. 20, chapter 2. The Mineralogical Society, Twickenham, UK, pp 59-131 
Gliozzo E, Grassi N, Bonanni P, Meneghini C, Tomei MA (2011) Gemstones from Vigna Barberini at the Palatine Hill (Rome, Italy). Archaeometry 53(3):469-489

Gliozzo E, Mattingly DJ, Cole F, Artioli G (2014) In the footsteps of Pliny: tracing the sources of Garamantian carnelian from Fazzan, south-west Libya. J Archaeol Sci 52:218-241

Götze J, Nasdala L, Kleeberg R, Wenzel M (1998) Occurrence and distribution of "moganite" in agate/chalcedony: a combined microRaman, Rietveld, and cathodoluminescence study. Contrib Minerol Petrol 133:96-105. https://doi.org/10.1007/s004100050440

Götze J, Tichomirowa M, Fuchs H, Pilot J, Sharp ZD (2001) Geochemistry of agates: a trace element and stable isotope study. Chem Geol 175:523-541. https://doi.org/10.1016/S0009-2541(00)00356 $-9$

Götze J, Möckel R, Kempe U, Kapitonov I, Vennemann T (2009) Characteristics and origin of agates in sedimentary rocks from the Dryhead area, Montana, USA. Mineral Mag 73:673-690. https://doi. org/10.1180/minmag.2009.073.4.673

Götze J, Nasdala L, Kempe U, Libowitzky E, Rericha A, Vennemann $\mathrm{T}$ (2012) The origin of black colouration in onyx agate from Mali. Mineral Mag 76:115-127. https://doi.org/10.1180/minma g.2012.076.1.115

Götze J, Gaft M, Möckel R (2015) Uranium and uranyl luminescence in agate/chalcedony. Mineral Mag 79:983-993. https://doi. org/10.1180/minmag.2015.079.4.08

Götze J, Möckel R, Vennemann T, Müller A (2016) Origin and geochemistry of agates in Permian volcanic rocks of the Sub-Erzgebirge basin, Saxony (Germany). Chem Geol 428:77-91. https:// doi.org/10.1016/j.chemgeo.2016.02.023

Haake R, Holzhey G (1989) Achate in kugelformigen Rhyoliten des Rotliegenden im sachsisch-thuringischem Raum. Chem Erde 49:173-183

Harris C (1988) Oxygen isotope geochemistry of a quartz-agate geode from north-western Namibia. Commun Geol Surv S W Africa/ Namibia 4: 49-51 http://www.mme.gov.na/files/publications/866_ Harris_O\%20isotopes\%20of\%20quartz-agate\%20geodes.pdf

Harris C (1989) Oxygen-isotope zonation of agates from Karoo volcanics of the Skeleton Coast, Namibia. Am Mineral 74:476-481

Heaney OJ (1993) A proposed mechanism for the growth of chalcedony. Contrib Mineral Petrol 115:66-74. https://doi.org/10.1007/ BF00712979

Heaney PJ, Davis AM (1995) Observation and origin of self-organized textures in agates. Science 269:1562-1565. https://doi. org/10.1126/science.269.5230.1562

Holzhey G (2001) Contribution to petrochemical-mineralogical characterization of alteration processes within the marginal facies of rhyolitic volcanic of lower Permian Age, Thuringian Forest, Germany. Chem Erde 61:149-186

Jourdan F, Féraud G, Bertramd H, Watkeys MK, Renne PR (2007) Distinct brief major events in the Karoo large igneous province clarified by new ${ }^{40} \mathrm{Ar} /{ }^{39} \mathrm{Ar}$ ages on the Lesotho basalts. Lithos 98:195-209. https://doi.org/10.1016/j.lithos.2007.03.002

Keyser N (1998) The geology and geochemistry of the Ventersdorp Supergroup in the area between Vryburg, Ottosdal and Mafikeng. Geol Surv S Afr Bull 122:117

Landmesser M (1995) "Mobility by metastability": silica transport and accumulation at low temperatures. Chem Erde 55:149-176

Landmesser M (1998) "Mobility by metastability" in sedimentary and agate petrology: applications. Chem Erde 58:1-22

Ledevin M (2013) Les cherts Archéens de la ceinture de roches vertes de Barberton (3.5-3.2 Ga), Afrique du Sud. Processus de formation et utilisation comme proxys paleo-environnementaux. Phd Thesis in Earth Sciences. Université de Grenoble, France https ://pdfs.semanticscholar.org/ba20/9cd4ccaef739c0a7a44244656 5adca80d2c5.pdf
Liu TG, Miah MRU, Schmitt R (1988) Cerium: a chemical tracer of paleo-oceanic redox conditions. Geochim Cosmochim Acta 52:1361-1371. https://doi.org/10.1016/0016-7037(88)90207-4

Lock BE, Reid DR, Broderick TJ (1974) Stratigraphy of the Karroo volcanic rocks in the Barkly East District. S Afr J Geol 77:117-29. https://hdl.handle.net/10520/AJA10120750_343

Luttinen AV (2018) Bilateral geochemical asymmetry in the Karoo large igneous province. Sci Rep. https://doi.org/10.1038/s4159 8-018-23661-3

Marsh JS, Eales HV (1984) The chemistry and petrogenesis of igneous rocks of the Karoo central area, Southern Africa. Geol Soc S Afr Spec Publ 13:27-67

Marsh JS, Hooper PR, Rehacek J, Duncan RA, Duncan AR (1997) Stratigraphy and age of Karoo basalts of Lesotho and implications for correlation within the Karoo igneous province. In: Mahoney JJ, Coffin MF (eds) Large igneous province: continental: oceanic and planetary flood volcanism, geophysical monograph series. American Geophysical Union, Washington, pp 247-272

Matsuhisa Y, Goldsmith JR, Clayton RN (1979) Oxygen isotopic fractionation in the system quartz-albite-anorthite-water. Geochim Cosmochim Acta 43:1131-1140. https://doi.org/10.1016/00167037(79)90099-1

McCarthy TS (1983) Evidence for the former existence of a major southerly flowing river in Griualand West. S Afr J Geol 86:37-49. https://hdl.handle.net/10520/AJA10120750_376

McCrank GFD, Misiura JD, Brown PA (1981). Plutonic rocks in Ontario. Geological Survey of Canada Paper 80-23, 171 pp. https ://doi.org/10.4095/109543

McDonough WF, Sun SS (1995) The composition of the Earth. Chem Geol 67:1050-1056. https://doi.org/10.1016/0009-2541(94)00140 $-4$

Merino E, Wang Y, Deloule E (1995) Genesis of agates in flood basalts: twisting of chalcedony fibers and trace-element geo-chemistry. Am J Sci 295:1156-1176. https://doi.org/10.2475/ajs.295.9.1156

Mitchell AA, Ramluckan VR, Dunlevey JN, Eglington BM (1996) The basalt stratigraphy of the Sani Pass, Kwazulu/Natal Drakensberg. S Afr J Geol 99:251-262. https://hdl.handle.net/10520/EJC-93477 $327 \mathrm{e}$

Möckel R, Götze J (2007) Achate aus sächsischen Vulkaniten des Erzgebirgischen Beckens. Veröff. Mus. f. Naturk. Chemnitz 30:25-60. http://mineralienkabinett.org/2007_moeckel_goetz e.pdf

Möckel R, Götze J, Sergeev SA, Kapitonov IN, Adamskaya EV, Goltsin NA, Vennemann T (2009) Trace-element analysis by laser ablation inductively coupled plasma mass spectrometry (LA-ICPMS): a case study for agates from Nowy Kościoł, Poland. SibFU 2:123-138

Mountain ED (1953) Agate pebbles on the south-eastern coast of the Union. S Afr J Geol 56:177-182. https://hdl.handle.net/10520/ AJA10120750_2186

Mourre V, Villa P, Henshilwood CS (2010) Early use of pressure flaking on lithic artifacts at Blombos cave, South Africa. Science 330:659-662. https://doi.org/10.1126/science. 1195550

Moxon JT (1996) Agate: microstructure and possible origin. Terra, Doncaster

Moxon JT (2017) A re-examination of water in agate and its bearing on the agate genesis enigma. Mineral Mag 81:1223-1244. https ://doi.org/10.1180/minmag.2017.081.002

Moxon T, Reed SJB (2006) Agate and chalcedony from igneous and sedimentary hosts aged 13 to $3480 \mathrm{Ma}$ : a cathodoluminescence study. Mineral Mag 70:485-498. https://doi.org/10.1180/00264 61067050347

Moxon T, Nelson DR, Zhang M (2006) Agate recrystallization: evidence from samples found in Archaean and Proterozoic host rocks, Western Australia. Aust J Earth Sci 53:235-248. https:// doi.org/10.1080/08120090500499255 
Moxon T, Reed SJB, Zhang M (2007) Metamorphic effects on agate found near the Shap granite, Cumbria, England: as demonstrated by petrography, X-ray diffraction and spectroscopic methods. Mineral Mag 71:461-476. https://doi.org/10.1180/minma g.2007.071.4.461

Moxon T, Petrone CM, Reed SJB (2013) Characterization and genesis of horizontal banding in Brazilian agate: an X-ray diffraction, thermogravimetric and electron microprobe study. Mineral Mag 77:227-248. https://doi.org/10.1180/minmag.2013.077.3.02

Partridge TC, Brink ABA (1967) Gravels and terraces of the lower Vaal basin. S Afr Geogr J 49:21-38. https://doi.org/10.1080/03736 245.1967.10559417

Pemberton J (1978) The geochemistry and petrology of Karroo basalts of the Barkly east area, north eastern Cape. Thesis presented for the degree of Master of Science at Rhodes University, Grahamstown

Porraz G, Texier P-J, Archer W, Piboule M, Rigaud J-P, Tribolo C (2013) Technological successions in the Middle Stone Age sequence of Diepkloof Rock Shelter, Western Cape, South Africa. J Archaeol Sci 40:3376-3400. https://doi.org/10.1016/j. jas.2013.02.012

Potgieter CD, Snyman CP, Förtsch EB (1982) Epigenetic laumontite in the Jurassic Clarens and Drakensberg Formations of the Karoo Sequence. S Afr J Geol 85:203-210. https://hdl.handle.net/10520 /AJA10120750_1085

Prinsloo LC, van der Merwe EM, Wadley L (2018) The thermal behaviour of silica varieties used for tool making in the Stone Age. J Therm Anal Calorim 131:1135-1145. https://doi.org/10.1007/ s10973-017-6602-z

Ramluckan VR (1992). The petrology and geochemistry of the Karoo Sequence basaltic rocks in the Natal Drakensberg at Sani Pass. M.Sc. thesis (unpublished, University of Durban-Westville (now KwaZuluNatal), Durban, South Africa

Rhodes RC, Krohn DH (1972) Tectonic control over regional geochemical variation in the Karroo basaltic Province of Southern Africa. S Afr J Geol 75:11-21. https://hdl.handle.net/10520/ AJA10120750_2744

Rudnick RL, Gao S (2003) the composition of the continental crust. In: Holland HG, Turekian KK (eds) Treatise on geochemistry, vol 3. The crust. Elsevier, Oxford, pp 1-64

Saunders JA (1990) Oxygen-isotope zonation of agates from Karoo volcanics of the Skeleton Coast, Namibia: discussion. Am Mineral 75:1205-1206. http://www.minsocam.org/ammin/AM75/ AM75_1205.pdf

Schmitt-Riegraf C (1996) Magmenentwicklung und spät-bis postmagmatische Alterationsprozesse permischer Vulkanite im Nordwesten der Nahe-Mulde. Münster Forsch Geol Paläont 80:1-251

Shields G, Stille P (2001) Diagenetic constraints on the use of cerium anomalies as palaeoseawater redox proxies: an isotopic and $\mathrm{REE}$ study of Cambrian phosphorites. Chem Geol 175:29-48. https:// doi.org/10.1016/S0009-2541(00)00362-4

Strauch G, Nitzsche H-M, Holzhey G (1994) Isotopenuntersuchungen an Rhyolithen und Achatbildungen. Neues Jb Miner Abh 165:103-104

Sumner PD, Hall KJ, van Rooy JL, Meiklejohn KI (2009) Rock weathering on the eastern mountains of southern Africa: review and insights from case studies. J Afr Earth Sci 55:236-244. https:// doi.org/10.1016/j.jafrearsci.2009.04.010

Tiepolo M, Bottazzi P, Palenzona M, Vannucci R (2003) A laser probe coupled with ICP-double focusing sector-field mass spectrometer for in situ analysis of geological samples and U-Pb dating of zircon. Can Mineral 41:259-272. https://doi.org/10.2113/gscan $\min .41 .2 .259$

van Achterbergh E, Ryan CG, Jackson SE, Griffin WL (2001) Data reduction software for LA-ICP-MS. In: Sylvester P (ed) Laserablation-ICPMS in the earth sciences: principles and applications, vol 29. Mineralogical Association of Canada, Ottawa, Ont., Canada, pp 239-243

Van der Westhuizen WA, de Bruiyn H, Meintjies PG (2006) The Ventersdorp Supergroup. In: Johnson MR, Anhaeusser CR, Thomas RJ (eds) The geology of South Africa. Council for Geoscience, Johannesburg, pp 187-208

Venneman TW, Morlok A, von Engelhardt W, Kyser K (2001) Stable isotope composition of impact glasses from the Nördlinger Ries impact crater, Germany. Geochim Cosmochim Acta 65:13251336. https://doi.org/10.1016/S0016-7037(00)00600-1

Wadley L, de la Peña P, Prinsloo LC (2017) Responses of South African agate and chalcedony when heated experimentally, and the broader implications for heated archaeological minerals. J Field Archaeol 42:364-377. https://doi.org/10.1080/00934 690.2017.1337438

Wang Y, Merino E (1990) Self-organizational origin of agates: banding, fiber twisting, composition, and dynamic crystallization model. Geochim Cosmochim Acta 54:1627-1638. https://doi. org/10.1016/0016-7037(90)90396-3

Wang Y, Merino E (1995) Origin of fibrosity and banding in agates from flood basalts. Am J Sci 295:49-77. https://doi.org/10.2475/ ajs.295.1.49

Wedepohl KH (1978) Handbook of Geochemistry. Springer, Berlin

Wilson MGC, McKenna N, Lynn MD (2007) The occurrence of diamonds in South Africa. Council for Geoscience, Pretoria, p 105

Wood SA (1990) The aqueous geochemistry of the rare-earth elements and yttrium. 2. Theoretical predictions of speciation in hydrothermal solutions to $350{ }^{\circ} \mathrm{C}$ at saturation water vapor pressure. Chem Geol 88:99-125. https://doi.org/10.1016/0009-2541(90)90106-H 